\title{
The Impact of Nanoparticles on Innate Immune Activation by Live Bacteria
}

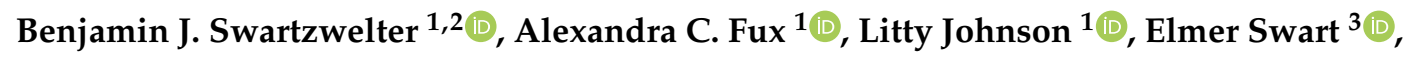

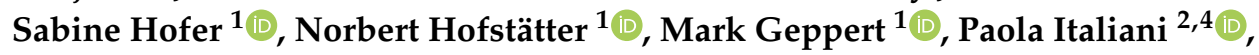

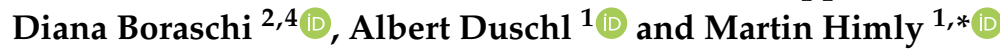 \\ 1 Department of Biosciences, Paris Lodron University of Salzburg (PLUS), 5020 Salzburg, Austria; \\ swartzwe@colorado.edu (B.J.S.); alexandra.fux@sbg.ac.at (A.C.F.); litty.johnson@sbg.ac.at (L.J.); \\ sabine.hofer@sbg.ac.at (S.H.); norbert.hofstaetter@sbg.ac.at (N.H.); mark.geppert@sbg.ac.at (M.G.); \\ albert.duschl@sbg.ac.at (A.D.) \\ 2 Institute of Biochemistry and Cell Biology, National Research Council, 80131 Napoli, Italy; \\ paola.italiani@ibbc.cnr.it (P.I.); diana.boraschi@ibbc.cnr.it (D.B.) \\ 3 UK Centre for Ecology and Hydrology (UKCEH), Wallingford OX10 8BB, UK; elmswa@ceh.ac.uk \\ 4 Stazione Zoologica Anton Dohrn, 80122 Napoli, Italy \\ * Correspondence: martin.himly@sbg.ac.at; Tel.: +43-662-8044-5713
}

Received: 25 November 2020; Accepted: 16 December 2020; Published: 18 December 2020

\begin{abstract}
The innate immune system evolved to detect and react against potential dangers such as bacteria, viruses, and environmental particles. The advent of modern technology has exposed innate immune cells, such as monocytes, macrophages, and dendritic cells, to a relatively novel type of particulate matter, i.e., engineered nanoparticles. Nanoparticles are not inherently pathogenic, and yet cases have been described in which specific nanoparticle types can either induce innate/inflammatory responses or modulate the activity of activated innate cells. Many of these studies rely upon activation by agonists of toll-like receptors, such as lipopolysaccharide or peptidoglycan, instead of the more realistic stimulation by whole live organisms. In this review we examine and discuss the effects of nanoparticles on innate immune cells activated by live bacteria. We focus in particular on how nanoparticles may interfere with bacterial processes in the context of innate activation, and confine our scope to the effects due to particles themselves, rather than to molecules adsorbed on the particle surface. Finally, we examine the long-lasting consequences of coexposure to nanoparticles and bacteria, in terms of potential microbiome alterations and innate immune memory, and address nanoparticle-based vaccine strategies against bacterial infection.
\end{abstract}

Keywords: engineered nanoparticles; innate immunity; inflammation; innate immune memory; toll-like receptors; pathogen-associated molecular patterns; lipopolysaccharide; biocorona; microbiota; nanovaccines; adjuvants

\section{Introduction}

\subsection{The Human Innate Immune Response}

The innate immune response begins with cellular or humoral recognition of danger, which alerts cells of the presence of potentially pathogenic foreign or endogenous materials. Upon recognition of danger, innate immune cells such as monocytes and macrophages rapidly initiate a response that includes phagocytosis and leads to inflammation, which are aimed at removal and destruction of the threatening object [1,2]. Activation of innate cells is generally initiated by pathogen binding to pattern recognition receptors (PRRs) expressed on the plasma membrane and on intracellular 
membranes. Ligand binding of PRRs initiates signalling pathways that lead to production and release of inflammatory factors, such as cytokines and chemokines, and upregulation of costimulatory surface molecules [3]. The classic example of a PRR-activating ligand is lipopolysaccharide (LPS), which is present on Gram-negative bacteria and activates the PRR toll-like receptor 4 (TLR4) [4,5]. Different pathogen-associated molecular patterns (PAMPs) bind other PRRs and lead to a similar inflammatory cell activation. Due to the fact that they potently stimulate innate immune responses, PRR ligands such as LPS are routinely used for in vitro activation and assessment of innate/inflammatory responses, particularly to examine the impact of drug candidates and biological materials [6]. In in vitro testing of novel biomedical products, the reaction of innate immune cells to LPS or other PAMPs is generally considered as a proxy for the general reaction to pathogenic stimulation, in order to obtain insight into whether a material may have a direct impact on or interfere with a normal innate immune response. Several important limitations of this experimental/screening approach should be considered. Innate immune cells typically come in contact with bacteria after they have crossed protective barriers such as the intestinal or respiratory epithelium, and thus in vivo the interaction mostly occurs with whole live bacteria. While PRR activation is a central component to the resulting immune response, innate cells also respond to other important physical and active aspects of bacterial invasion such as the shape and size, and the spatial organization of PAMPs on the bacterial surface [7,8]. Additionally, bacterial motility and proliferation can dramatically impact defensive cell activation [9]. In vitro models that attempt to simulate the in vivo response should therefore consider the use of whole and live bacteria, to more completely mimic the processes inherent to an immune response to infection. Based on such considerations, a re-evaluation of the immunological effects of engineered nanoparticles (NPs) may be necessary, as the majority of nanoparticle related studies do not address the impact of nanoparticles in the context of challenge by live bacteria.

\subsection{Current State of Nanotechnology from a Biological Perspective}

Nanotechnology is one of the key technologies of the 21st century with many applications, including in biomedical sciences. NPs (i.e., particles with dimensions of 1-100 $\mathrm{nm}$ ) can be composed of different materials and can appear in different sizes, shapes, and with different surface functionalization. Silicon dioxide $\left(\mathrm{SiO}_{2}\right)$, titanium dioxide $\left(\mathrm{TiO}_{2}\right)$, and zinc oxide $(\mathrm{ZnO})$ NPs are the most produced types of NPs worldwide [10]. Applications can be found in electronics $\left(\mathrm{SiO}_{2}\right)$, manufacturing and construction (e.g., car tires, concrete, sports equipment; $\mathrm{SiO}_{2}, \mathrm{TiO}_{2}$, and also aluminum oxide, $\mathrm{Al}_{2} \mathrm{O}_{3}$, and carbon nanotubes or graphene), food additives $\left(\mathrm{SiO}_{2}\right.$ and $\left.\mathrm{TiO}_{2}\right)$, food contact materials or textiles (silver, $\mathrm{Ag}$ ), paintings $\left(\mathrm{TiO}_{2}\right)$, and sunscreens $\left(\mathrm{TiO}_{2}\right.$ and $\left.\mathrm{ZnO}\right)$ among others [11-13]. Despite their broad applications, there is evidence that certain NPs can induce cell stress and/or toxicity or cause unwanted immune reactions $[14,15]$. Thus, a manifold of "safe-by-design" strategies have been developed during the past decades in the attempt to design safer nanomaterials [16]. From a biomedical standpoint, many NP formulations can be used for therapeutic benefit. Iron oxide NPs can function as contrast agents in magnetic resonance imaging, for tumour therapy by magnetic hyperthermia, for iron replacement therapy, and are in development for use in drug delivery [17-19]. Gold (Au) NPs offer a number of potential medical applications in various areas, including bioimaging, sensing, diagnosis, and functionalization for therapeutic purposes [20]. Biomedically useful organic and biodegradable NPs such as poly-lactic-co-glycolic acid (PLGA) NPs have been approved by the US Food and Drug Administration and the European Medicines Agency as drug delivery systems [21-23]. Nanomedical applications are also under development for passive or active drug targeting in the field of cancer treatment [24], and have great potential in vaccination [25] and immunotherapeutic approaches [26,27].

The synthesis methods for generating NPs include gas-phase and wet-chemical methods, and procedures involving organic solvents that extend even to the production of biocompatible and biodegradable nanomaterials [28-31]. Elimination of organo-chemical residues is particularly important in NPs meant for biological application. Wet-chemical methods may be especially prone to contamination of the resulting NPs with bacterial components such as endotoxin (i.e., LPS) that, 
even after sterilization, can induce an inflammatory response that may be mistakenly attributed to particles [32]. Nanomaterials may interact with humans at multiple levels throughout their life cycle, with exposure scenarios ranging from food additives and consumer products to the workplace and the medical field. This implies that the interaction may occur at the level of different barrier tissues and that the NP exposure doses may significantly vary. Besides human exposure, we should be aware that manufacturing, use, and disposal of such nanomaterials may be also detrimental to the environment where they may exert undesirable effects on the entire biosphere, including microorganisms [33,34]. This may again lead to indirect effects on human health by impacting biodiversity in the environment, and thus the food chain, and the microbiota in symbiosis with humans. In each case, from synthesis to environmental effects or direct particle exposure, the potential exists for nanoparticles to impact human health.

The direct effects of different nanomaterials on the innate immune system have been reviewed earlier [35-37]. NPs can enter the human body by different routes such as inhalation, ingestion, injection, or skin contact (depicted in Figure 1). Some inhaled or ingested NPs have been shown to penetrate the relevant biological barriers, the alveolar epithelium, or the intestinal epithelium [38]. While dermal penetration can be considered as a minor entry route of NPs, some studies provided evidence that NPs can to a certain extent penetrate the protective layers of the skin, in particular if the skin presents anomalies [39,40]. Once inside the body, NPs can interact with different components of the innate immune system, such as neutrophils, monocytes, macrophages, dendritic cells, natural killer cells, etc. [36,41]. Furthermore, NPs may also impact adaptive immune responses for example by modulating the function of dendritic cells in antigen presentation [35]. The question of whether or not a nanomaterial can be considered as immunologically safe is heavily discussed in the current literature and depends on numerous factors, including the condition of the target host [42,43]. For instance, elderly people or people with chronic diseases are more likely to develop detrimental reactions to NPs that pose no problem to healthy people in identical exposures [44]. Other factors depend on the nanomaterial itself (size, shape, and composition), its potential contamination (especially with LPS), its concentration upon exposure and the sensitivity of the target host [45]. While the capacity of NPs to directly impact the immune system has been extensively studied, far less literature exists on the impact of NPs upon coexposure with infectious pathogens. Within this review we focus on the capacity of NPs to affect the innate immune activation triggered by live bacteria, thereby modulating the course of a normal defensive innate/inflammatory reaction. We have chosen to focus on NPs that are not functionalized with specific molecules, in order to examine the direct impact of the bionano interaction on the antibacterial immune response.

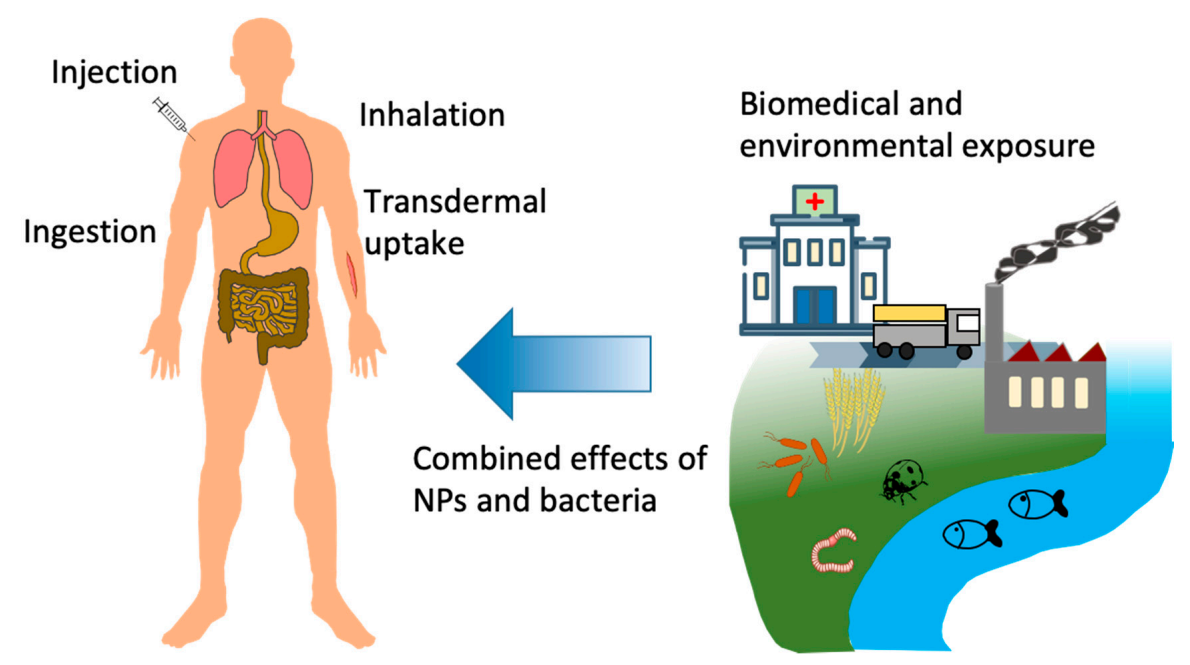

Figure 1. Overview of potential coexposure scenarios/interactions of nanoparticles (NPs) with ubiquitous bacteria/bacterial components, and main routes of uptake into the human body. 


\section{The Effects of NPs on Innate Immune Stimulation}

Many in vitro models that investigate the interaction of novel NP formulations with innate immune activation use synthetic or purified ligands that activate monocytes, macrophages, or other PRR-expressing cells. PRR-based cell activation leads to production of molecules involved in the defensive inflammatory reaction, including costimulatory surface molecules and soluble factors such as cytokines and chemokines. Several scenarios exist in which unfunctionalized NPs may interfere with and alter both the initiation and progression of inflammatory responses induced by microbial or other stimuli. Of most concern from a pathological standpoint is the possibility that NPs could exacerbate or prolong PRR-driven inflammatory reactions, leading to uncontrolled tissue-damaging inflammation. For instance, NPs may synergize with and amplify the effects of the bacterial stimulation. An exemplary case is the production of interleukin-1 $\beta$ (IL-1 $\beta$ ). LPS binding to TLR4 upregulates, through the transcription factor $\mathrm{NF} \kappa \mathrm{B}$, the gene encoding the potent inflammatory cytokine IL-1 $\beta$ [46]. IL- $1 \beta$ is produced as an inactive pro-protein that needs enzymatic cleavage before being exported extracellularly as biologically active IL- $1 \beta$. This usually requires a second signal involving activation of the NOD-, LRR-, and pyrin domain-containing protein 3 (NLRP3) inflammasome, which induces the enzyme caspase- 1 to cleave pro-IL-1 $\beta$ [47,48]. Active IL- $1 \beta$ then leaves the cell and binds to IL- 1 receptors (which are present on most cells in the body, erythrocytes being an exception) and triggers defensive activation responses [49]. If uncontrolled in duration and intensity, IL-1 $\beta$-induced inflammation can lead to pathological symptoms such as vasodilation, leukocyte influx, swelling, fever, and eventually inflammation-driven tissue damage may occur [50]. Silica NPs, multiwalled carbon nanotubes and many other NP types have been shown to be potent inducers of NLRP3 inflammasome activation, an event that could contribute to the establishment of uncontrolled pathological inflammation [51,52]. Conversely, NLRP3 activation by NPs could be exploited in a beneficial manner in the case of adjuvant function, where activation of the innate immune system is desirable for induction of long-lasting adaptive immunity $[4,26]$.

Although some NPs may enhance inflammation by acting on NLRP3 activation, in several cases, it was observed that an inflammatory response to inflammatory stimuli could be downregulated by the presence of NPs. This is most commonly reported in terms of reduced cytokine production in response to LPS stimulation. Nanoplatinum was observed to suppress the production of cytokines and reactive oxygen species (ROS) in LPS-stimulated mouse macrophage-like leukemia cells [53]. Grosse et al. demonstrated an inhibition of the response to LPS in terms of production of tumor necrosis factor-alpha (TNF $\alpha$ ), IL-1 $\beta$, and IL-6 when human primary monocytes were exposed to iron oxide NPs, an effect more pronounced at higher particle concentrations but smaller particle sizes [54]. Possible explanations include a NP "cleaning" effect, in which the stimulant (as in the case of IL-1 $\beta$ ) is adsorbed onto the particle surface limiting its capacity to bind to its receptor [55]. Other evidence demonstrated that mouse bone marrow macrophages preexposed to superparamagnetic iron oxide NPs (SPIONs) exhibit a more inflammatory gene activation profile in response to LPS, raising another potential pathway for altering LPS-induced reactivity [56]. However, as experiments with similarly sized metallic or silica NPs failed to interfere with LPS-induced inflammation [32,56], it is likely that the NP effects may depend on the particle type and concentration, the exposure characteristics (before LPS, concurrent with LPS, etc.), the cell type (transformed vs. primary, human vs. murine) and the assay conditions.

We noted that in many cases, exposing innate immune cells to NPs has no effect on cellular reactivity to inflammatory stimuli, in spite of the fact that cells recognize and uptake the particles to which they are exposed $[6,57,58]$. This phenomenon is likely widely underreported, as it is inherently a "no-result" outcome, and these data have a tendency to be omitted from the literature. We also noted that much of the literature concerning NPs and immune activation regards the mechanistic aspects of the interaction, and uses particle and stimulant doses that are poorly related to realistic human exposure scenarios [45].

Some examples for the impact of unfunctionalized NPs on innate immune activation can be found in Table 1. 
Table 1. Overview on studies investigating the effect of NPs on innate immune cell activation.

\begin{tabular}{|c|c|c|c|c|c|c|c|c|}
\hline \multirow[t]{2}{*}{ NP Type (Size, Dose, Shape) } & \multirow[t]{2}{*}{$\begin{array}{l}\text { Stimulus } \\
\text { (Receptor) }\end{array}$} & \multicolumn{3}{|c|}{$\begin{array}{c}\text { Effect on } \\
\text { Stimulus-Induced } \\
\text { Innate Response }\end{array}$} & \multirow[t]{2}{*}{ Cell Type } & \multirow[t]{2}{*}{ Notes } & \multirow[t]{2}{*}{$\begin{array}{l}\text { Discusses NP } \\
\text { Dose Selection }\end{array}$} & \multirow[t]{2}{*}{$\operatorname{Ref}$} \\
\hline & & $\uparrow$ & $\downarrow$ & $=$ & & & & \\
\hline \multirow{2}{*}{$\begin{array}{c}\mathrm{Au} \\
5-35 \mathrm{~nm} \\
10-70 \mu \mathrm{g} / \mathrm{mL} \\
\text { not available (n/a) }\end{array}$} & $\begin{array}{c}\mathrm{IL}-1 \beta \\
(\mathrm{IL}-1 \mathrm{R} 1)\end{array}$ & & $x$ & & \multirow{2}{*}{$\begin{array}{l}\text { Human THP-1 } \\
\text { monocyte-like } \\
\text { leukemia cells }\end{array}$} & \multirow{2}{*}{$\begin{array}{l}\text { Induction of } \\
\text { cytokine production }\end{array}$} & \multirow{2}{*}{$\begin{array}{l}\text { No, some experiments } \\
\text { addressed surface area }\end{array}$} & \multirow{2}{*}[55]{} \\
\hline & $\begin{array}{c}\text { R848 } \\
\text { (TLR7/8) }\end{array}$ & & & $x$ & & & & \\
\hline $\begin{array}{c}25 \mathrm{~nm} \\
10 \mu \mathrm{g} / \mathrm{mL} \\
\text { spherical }\end{array}$ & LPS (TLR4) & & & $x$ & $\begin{array}{l}\text { Human primary } \\
\text { monocytes }\end{array}$ & $\begin{array}{l}\text { Induction of } \\
\text { cytokine production }\end{array}$ & $\begin{array}{l}\text { Yes, endotoxin-free } \\
\text { concentrations used }\end{array}$ & [59] \\
\hline $\begin{array}{c}\mathrm{Au}(10 \mathrm{~nm}), \mathrm{Ag}(14 \mathrm{~nm}) \\
1.3-12 \mu \mathrm{g} / \mathrm{mL} \\
\text { spherical }\end{array}$ & $\begin{array}{l}\mathrm{LPS}+\mathrm{TNF} \alpha \\
(\mathrm{TLR} 4+\mathrm{TNFR})\end{array}$ & & & $x$ & $\begin{array}{l}\text { Human primary } \\
\text { monocytes }\end{array}$ & $\begin{array}{l}\text { Kinetic evaluation of cytokine } \\
\text { expression and production }\end{array}$ & $\begin{array}{l}\text { Yes, concentrations chosen } \\
\text { based on cytotoxicity and } \\
\text { endotoxin assays }\end{array}$ & [6] \\
\hline $\begin{array}{c}\mathrm{Pt} \\
2.4 \mathrm{~nm} \\
10-1000 \mu \mathrm{M} \\
\mathrm{n} / \mathrm{a}\end{array}$ & LPS (TLR4) & & $x$ & & $\begin{array}{l}\text { Mouse RAW } 264.7 \\
\text { macrophage-like } \\
\text { leukemia cells }\end{array}$ & $\begin{array}{l}\text { Induction of cytokine and } \\
\text { ROS production }\end{array}$ & $\begin{array}{c}\text { No, use of different } \\
\text { concentrations not discussed }\end{array}$ & {$[53]$} \\
\hline $\begin{array}{c}\text { Iron oxide } \\
58.7 \mathrm{~nm} \\
1-50 \mu \mathrm{g} / \mathrm{mL} \\
\mathrm{n} / \mathrm{a}\end{array}$ & $\begin{array}{l}\text { LPS } 100 \\
\mathrm{ng} / \mathrm{mL} \\
\text { (TLR4) }\end{array}$ & & $x$ & $\times$ & $\begin{array}{l}\text { Primary murine } \\
\text { microglial cells }\end{array}$ & $\begin{array}{l}\text { Particle accumulation in } \\
\text { lysosomes, decreased IL-1 } \beta \\
\text { but not TNF } \alpha \text { production }\end{array}$ & Utilized a dose response & {$[60]$} \\
\hline $\begin{array}{c}\mathrm{n} / \mathrm{a} \\
0-30 \mathrm{mg} / \mathrm{mL} \\
\mathrm{n} / \mathrm{a}\end{array}$ & $\begin{array}{c}\text { Apoptotic } \\
\text { cancer cells } \\
\text { (Scavenger R) }\end{array}$ & $\times$ & & & $\begin{array}{c}\text { Mouse RAW } 264.7 \\
\text { macrophage-like } \\
\text { leukemia cells in } \\
\text { coculture with other } \\
\text { cancer cells (in vitro); } \\
\text { tumor-associated } \\
\text { macrophages } \\
\text { (in vivo) }\end{array}$ & $\begin{array}{l}\text { In vitro: } \mathrm{M} 1 \text { cell polarization } \\
\text { In vivo: M1 polarization at } \\
\text { day 7; M2 polarization at day } 21\end{array}$ & $\begin{array}{l}\text { Yes, doses chosen were } \\
\text { related to human } \\
\text { administered doses } \\
\text { of ferumoxytol }\end{array}$ & {$[61]$} \\
\hline $\begin{array}{l}10,30 \mathrm{~nm} \\
1-100 \mu \mathrm{g} / \mathrm{mL} \\
\text { spherical }\end{array}$ & LPS (TLR4) & & $x$ & & $\begin{array}{l}\text { Human primary } \\
\text { monocytes }\end{array}$ & $\begin{array}{l}\text { Induction of TNF } \alpha, \text { IL- } 6 \text { and } \\
\text { IL-1 } \beta \text { production }\end{array}$ & Utilized a dose response & [54] \\
\hline
\end{tabular}


Table 1. Cont

\begin{tabular}{|c|c|c|c|c|c|c|c|c|}
\hline \multirow[t]{2}{*}{ NP Type (Size, Dose, Shape) } & \multirow[t]{2}{*}{$\begin{array}{l}\text { Stimulus } \\
\text { (Receptor) }\end{array}$} & \multicolumn{3}{|c|}{$\begin{array}{c}\text { Effect on } \\
\text { Stimulus-Induced } \\
\text { Innate Response }\end{array}$} & \multirow[t]{2}{*}{ Cell Type } & \multirow[t]{2}{*}{ Notes } & \multirow[t]{2}{*}{$\begin{array}{l}\text { Discusses NP Dose } \\
\text { Selection }\end{array}$} & \multirow[t]{2}{*}{$\operatorname{Ref}$} \\
\hline & & $\uparrow$ & $\downarrow$ & $=$ & & & & \\
\hline $\begin{array}{c}11 \mathrm{~nm} \\
2 \mu \mathrm{g} / \mathrm{mL} \\
\text { spherical }\end{array}$ & $\begin{array}{l}\mathrm{LPS}+\mathrm{TNF} \alpha \\
(\mathrm{TLR} 4+\mathrm{TNFR})\end{array}$ & & & $\times$ & $\begin{array}{l}\text { Human primary } \\
\text { monocytes }\end{array}$ & $\begin{array}{c}\text { Kinetic analysis of expression } \\
\text { and production of IL-1 } \beta \\
\text { and IL-1Ra }\end{array}$ & $\begin{array}{l}\text { Yes, selected the highest } \\
\text { endotoxin-free concentration }\end{array}$ & [62] \\
\hline $\begin{array}{c}\text { Lipid-modified glycol-split } \\
\text { heparin } \\
110,160 \mathrm{~nm} \\
0.5 \mathrm{mg} / \mathrm{mL} \\
\text { spherical }\end{array}$ & $\begin{array}{l}\text { LPS (TLR4), } \\
\text { PAM3CSK4 } \\
\text { (TLR1/2), } \\
\text { Poly(I:C) } \\
\text { (TLR3) }\end{array}$ & & $x$ & $x$ & $\begin{array}{l}\text { Mouse peritoneal } \\
\text { macrophages }\end{array}$ & $\begin{array}{l}\text { Signal transduction and } \\
\text { cytokine production inhibited } \\
\text { only in LPS-activated cells }\end{array}$ & Utilized a dose response & [63] \\
\hline $\begin{array}{c}\text { PCL-PEG } \\
70-130 \mathrm{~nm} \\
1-100 \mu \mathrm{g} / \mathrm{mL} \\
\text { n/a }\end{array}$ & LPS (TLR4) & & & $\times$ & $\begin{array}{l}\text { Human primary } \\
\text { monocytes }\end{array}$ & $\begin{array}{l}\text { Induction of TNF } \alpha \text { and IL-1 } \beta \\
\text { production }\end{array}$ & $\begin{array}{c}\text { NP concentration equalized } \\
\text { for surface area, } \\
\text { no explanation for } \\
\text { dose selection }\end{array}$ & {$[58]$} \\
\hline $\begin{array}{l}\text { Pristine graphene } \\
100-1000 \mu \mathrm{m} \\
20-100 \mu \mathrm{g} / \mathrm{mL} \\
\text { crystalline }\end{array}$ & $\begin{array}{l}\text { LPS (TLR4) } \\
\text { in vitro, heat } \\
\text { killed E. coli } \\
\text { ex vivo }\end{array}$ & $\times$ & & $\times$ & $\begin{array}{c}\text { Mouse ex vivo } \\
\text { peritoneal } \\
\text { macrophages and } \\
\text { bone marrow-derived } \\
\text { dendritic cells }\end{array}$ & $\begin{array}{l}\text { NLRP3 inflammasome } \\
\text { activation and IL-1 } \beta \text { production } \\
\text { (increase), IL-6 and IL-12p70 } \\
\text { production (unchanged) }\end{array}$ & Yes, sub-toxic dose selected & [64] \\
\hline $\begin{array}{l}\text { Carbon black } \\
14,56 \mathrm{~nm} \\
4 \mathrm{mg} / \mathrm{kg} \\
\mathrm{n} / \mathrm{a}\end{array}$ & LPS (TLR4) & $\times$ & & & In vivo mouse lung & $\begin{array}{l}\text { Lung inflammation (histology) } \\
\text { and cytokines production } \\
\text { (IL-6, TNF } \alpha)\end{array}$ & Referenced previous work & [65] \\
\hline $\begin{array}{c}\mathrm{CeO}_{2} \\
3-5 \mathrm{~nm} \\
1 \mathrm{nM}-10 \mu \mathrm{M} \\
\text { crystalline }\end{array}$ & $\mathrm{LPS}+\mathrm{IFN} \gamma$ & & $x$ & & $\begin{array}{l}\text { Mouse J774.A1 } \\
\text { macrophage-like } \\
\text { histiocytic } \\
\text { lymphoma cells }\end{array}$ & $\begin{array}{l}\text { ROS production, iNOS protein } \\
\text { production }\end{array}$ & $\begin{array}{l}\text { Yes, dose responses } \\
\text { were used }\end{array}$ & {$[66]$} \\
\hline
\end{tabular}

IL-1R1: Interleukin 1 receptor 1; TNFR: TNF receptor; Pt: platinum; PCL: poly(e-caprolactone); PEG: polyethylene glycol; ROS: reactive oxygen species; INOS: inducible nitric oxide synthase. 


\section{The Effect of NPs on Innate Immune Activation by Live Bacteria}

Activation of innate immune responses by bacteria typically occurs, as already mentioned, principally through recognition of bacterial surface patterns by PRRs, including TLRs. In addition, microorganisms that enter the cytosol can be recognized by a class of cytosolic PRRs, the NOD-like receptors (NLRs). While these are the most likely and potent mechanisms of innate immune activation, in the case of bacterial stimulation several additional variables must be considered beyond the ligand-receptor based effect. A primary task of the innate immune response is to restrict bacterial growth and spread. Malfunctioning or suppressed immune responses, for instance in the case of diabetic chronic wounds, can result in uncontrolled bacterial proliferation leading to chronic and tissue-damaging infection [67].

Upon recognition of potentially dangerous agents such as bacteria, macrophages attempt to engulf the threat for destruction and elimination by activating the energy-expensive process of phagocytosis [2]. The efficiency of cell-mediated host defense also depends upon effective and rapid capture of motile bacteria and on the motility of phagocytes themselves [68,69]. Some bacteria such as Staphylococcus aureus have evolved an active immune avoidance mechanism by secreting biofilms, which strongly decrease immune detection or even drive the activation of immunosuppressive cells [70,71]. Further, some bacterial species are capable of intracellular survival, residing within phagosomes and preventing their fusion with lysosomes to escape phagolysosome-based destruction [72]. These processes are dynamic, adding increased levels of physical and chemical complexity that are not mimicked by PPR activation with soluble ligands such as LPS. This underlines the significant difference, in terms of molecular and functional mechanisms engaged in the response, between ligand-induced PPR stimulation (mimicking a late response, once bacteria have been destroyed and only single molecules are still present, with only PRR stimulation still occurring), uptake of dead bacteria (mimicking an intermediate phase of the response, once bacteria have been killed extracellularly but not yet destroyed; PRR stimulation and phagocytosis still occurring), and interaction with live bacteria (mimicking the first phases of the responses, with PRR stimulation, phagocytosis, proliferation restriction, and bacterial killing occurring). Thus, in vitro assays exclusively based on PPR stimulation would only reproduce the late phase of an innate immune response to bacteria and may not be predictive of the possible interference of NPs in particular with the early innate reaction to bacteria. This becomes particularly important in scenarios where coexposure to NPs and bacteria may take place. Certainly, in consumer or occupational exposure to NPs in the respiratory or digestive tract an interaction with the microbiota colonizing the respiratory and digestive mucosae is expected [73,74]. NPs may also be applied topically for a variety of purposes, where interactions with epidermal bacteria would be unavoidable [75]. Increased use of NPs in modern society makes it likely that coexposure to bacteria and NPs will become more common.

NPs can interact with bacteria in multiple ways, thereby interfering with the bacterial capacity to activate innate immune responses (Figure 2). It should be noted that small NPs $(\leq 30 \mathrm{~nm}$ ) may adhere to the bacterial surface, blocking as much as $80 \%$ of the bacterial surface area from contact with target cells and subsequent cell activation [76]. NP coating could thus serve the dual purpose of inhibiting bacterial infectivity and motility and masking the PAMPs to which TLRs or NLRs would otherwise bind [77]. It has been shown that pretreatment with $\mathrm{Au}$ or $\mathrm{SiO}_{2} \mathrm{NPs}$ can inhibit killed E. coli phagocytosis by RAW 264.7 cells [78], although this may not in fact alter the course of an inflammatory response to E. coli infection [79]. Similarly, SPIO NPs could decrease uptake of killed Staphylococcus pneumoniae in bone marrow-derived mouse macrophages [56]. The general evidence that NPs inhibit bacterial phagocytosis leads to the hypothesis that they can also inhibit innate cell activation by bacteria. Indeed, data from our group show that pretreatment with Au NPs decreases the response of primary human monocytes to live Bacille Calmette-Guérin (BCG, a strain of Mycobacterium bovis used as a tuberculosis vaccine) in terms of cytokine production, although the NPs had no effect on LPS stimulation [59]. The mechanism remains unclear. 


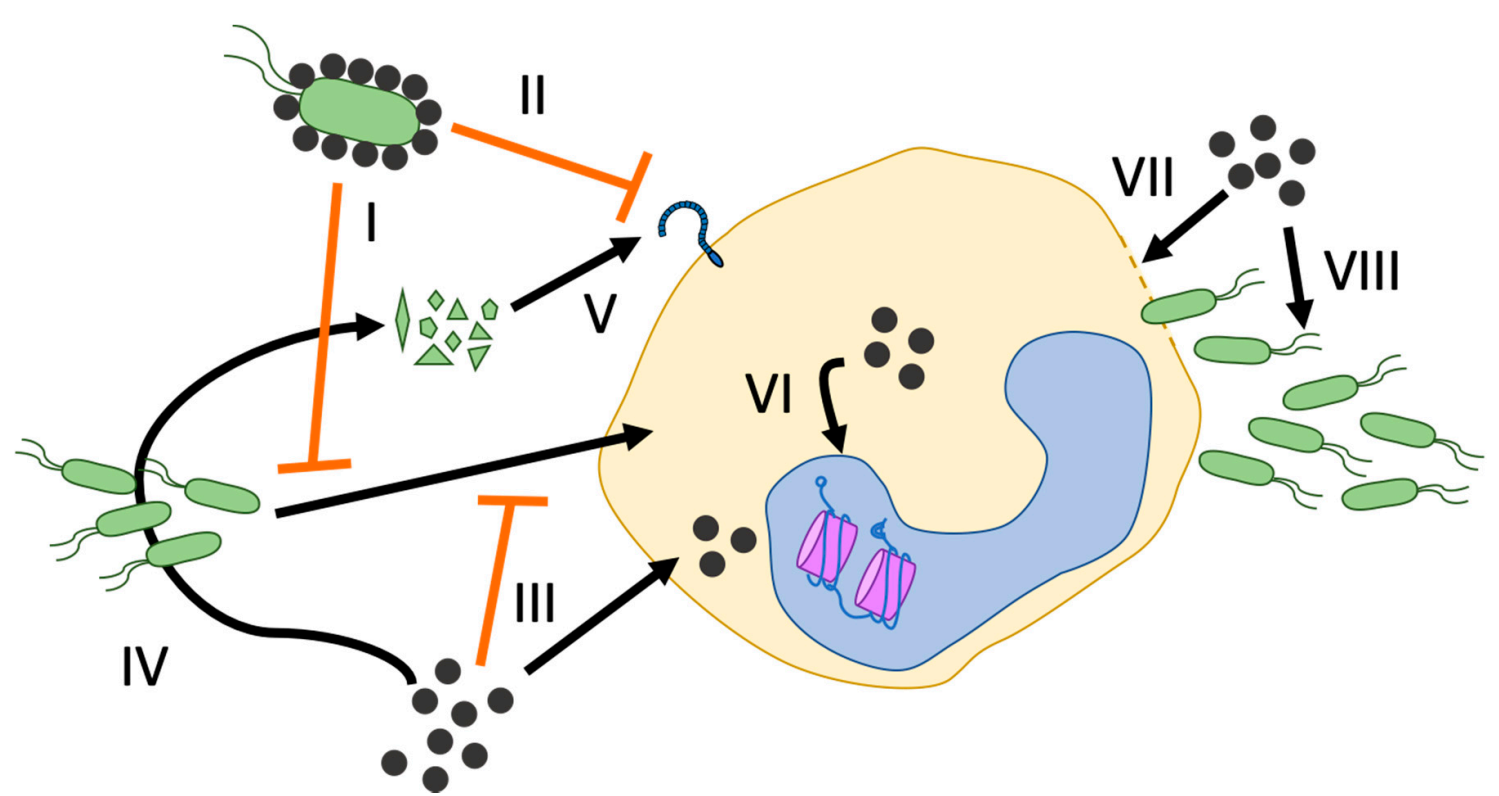

Figure 2. A schematic representation of the different avenues by which NPs may impact the innate immune response against bacteria. NPs (black dots) may interfere with the activation of innate cells (e.g., macrophages) by bacteria (green) in different negative and positive ways: (I) NP coating of bacteria can inhibit bacterial uptake into cells; (II) NP coating of bacteria can mask surface PAMPs and activation of cellular PRR; (III) NPs may compete with bacteria for cellular phagocytosis; (IV) NPs may have bactericidal activity resulting in release of PAMPs (small green polygons) leading to (V) PRR activation; (VI) NPs may induce epigenetic modifications (nucleosomes depicted in magenta); (VII) NP-mediated cytotoxicity causing cell membrane disruption and cell or tissue leakiness for bacterial invasion; and (VIII) NPs may enhance bacterial growth.

While the aforementioned studies describe models using safe and biomedically relevant particles, toxic NP types could enhance the detrimental impact of bacterial infections. Especially in the case of occupational exposure, disruption of tissue homeostasis by toxic NPs could open the door for pathogenicity. Particles resulting from welding fumes were observed to be particularly dangerous in this regard, with exposure driving inflammation and eventually increasing susceptibility to pneumococcal disease $[80,81]$. Likewise, inhalation of toxic copper oxide $(\mathrm{CuO}) \mathrm{NPs}$ impaired the mouse capacity to clear a lung infection by Klebsiella pneumoniae [82]. While these NPs do not have a direct synergistic effect on bacterial growth, it is clear that agents that cause tissue damage and impair immune functions facilitate rapid bacterial growth and infectious spread $[83,84]$. The possibility that certain NP types could have a direct positive influence on bacterial growth should not be ignored [85], although data on the topic remain scant. 
The bactericidal capacity of certain NPs is the most commonly reported scenario in which NPs can contribute to an effective immune reaction. Live bacteria induce immune responses of greater magnitude than their killed counterparts $[9,86]$. It can thus be hypothesized that the impact of NPs on immune activation caused by live bacteria could be far different than that on responses induced by PAMPs or killed bacteria. Silver NPs are perhaps the best studied particles in this regard. Ag NPs have a potent bactericidal activity mainly due to the release of toxic Ag ions that negatively impact membrane permeability and respiration $[87,88]$. Moreover, Ag NPs have also been found to enter the bacterial cells, where the high reactivity of silver may interfere with processes relating to sulphur (abundant on cell membranes) or phosphorus (abundant in compounds such as DNA) containing compounds [87,88]. More recently, Ag NPs have been demonstrated as effective antibiofilm agents, although it is unclear whether the particles act at the biofilm level or exclusively on bacteria [89]. Dependent upon the NP type, NPs could also contribute to biofilm formation [90]. The antimicrobial activity of other NP types, including $\mathrm{ZnO}$, iron oxide, and mesoporous silica, is extensively reviewed elsewhere [91-93]. The use of NPs as antimicrobial agents is of great interest, in particular in the case of antibiotic-resistant infections [93]. Inhibition of bacterial proliferation and subsequent killing of pathogenic bacteria is the objective of treatment against bacterial infection, and NP-based treatments are already in use in this regard [94]. However, in scenarios such as bacterially driven sepsis, bacteriolysis following certain antibiotic treatments is known to liberate membrane-bound bacterial components such as LPS leading to excessive pathological inflammation due to uncontrolled PRR activation [95]. The same could be a pitfall for NP-caused bacteriolysis.

Direct comparison between PAMP-induced responses and responses to live bacteria is not easy, since the two responses are different. In any case, it is clear that NPs can impact both types of reaction, and that the effect of NPs on PAMP-induced innate activation is not necessarily predictive of their impact on the response to live bacteria. The possibility of using unfunctionalized NPs for modulating innate reactions to bacteria in a beneficial direction is however promising and opens the way to future applications. Table 2 summarizes some recent findings on the subject. 
Table 2. Overview on studies on the impact of NPs on innate immune stimulation by live bacteria.

\begin{tabular}{|c|c|c|c|c|c|c|c|c|}
\hline \multirow[t]{2}{*}{ NP Type (Size, Dose, Shape) } & \multirow[t]{2}{*}{ Stimulus } & \multicolumn{3}{|c|}{$\begin{array}{l}\text { Effect on Bacteria- } \\
\text { Induced Response }\end{array}$} & \multirow[t]{2}{*}{ Cell Type } & \multirow[t]{2}{*}{ Notes } & \multirow{2}{*}{$\begin{array}{l}\text { Discusses NP Dose } \\
\text { Selection }\end{array}$} & \multirow[t]{2}{*}{ Ref } \\
\hline & & $\uparrow$ & $\downarrow$ & $=$ & & & & \\
\hline $\begin{array}{c}\mathrm{Au} \\
13 \mathrm{~nm} \\
0.17-17 \mathrm{mg} / \mathrm{kg} \\
\text { spherical }\end{array}$ & E. coli & & & $x$ & In vivo mouse & $\begin{array}{l}\text { Intravenous delivery daily } \\
\text { during the course of } \\
\text { the infection }\end{array}$ & No & [79] \\
\hline $\begin{array}{c}25 \mathrm{~nm} \\
10 \mu \mathrm{g} / \mathrm{mL} \text { spherical }\end{array}$ & BCG & & $x$ & $\times$ & $\begin{array}{l}\text { Human primary } \\
\text { monocytes }\end{array}$ & $\begin{array}{c}\text { Endpoint: production of TNF } \alpha, \\
\text { IL-6 and IL-10 (inhibited), } \\
\text { IL-1Ra (unchanged) }\end{array}$ & $\begin{array}{l}\text { Yes, endotoxin-free } \\
\text { concentrations used }\end{array}$ & [59] \\
\hline $\begin{array}{c}\mathrm{Au} \\
10,300 \mathrm{~nm} \\
5,10 \mathrm{mg} / \mathrm{mL} \text { spherical } \\
\mathrm{SiO}_{2} \\
10,300 \mathrm{~nm} \\
5,10 \mathrm{mg} / \mathrm{mL} \\
\text { spherical }\end{array}$ & E. coli & & $x$ & & $\begin{array}{l}\text { Mouse RAW } 264.7 \\
\text { macrophage-like } \\
\text { leukemia cells }\end{array}$ & $\begin{array}{l}\text { Pretreatment with } \mathrm{Au} \text { and } \mathrm{SiO}_{2} \\
\text { cells displayed reduced } \\
\text { phagocytosis of FITC labeled } \\
\text { E. coli (no inflammation data for } \\
\text { bacterial exposure) }\end{array}$ & $\begin{array}{l}\text { Yes, dosimetry data based on } \\
\text { relevant dose metrics } \\
\text { (by area, by number, } \\
\text { by volume) specifically } \\
\text { designed for a functional } \\
\text { study, checked for artificial } \\
\text { overdosing; no relation to } \\
\text { human exposure }\end{array}$ & {$[78]$} \\
\hline $\begin{array}{c}\mathrm{SiO}_{2} \\
30,140 \mathrm{~nm} \\
25 \% \text { bacterial coverage } \\
\text { spherical }\end{array}$ & $\begin{array}{l}\text { E. coli, } \\
\text { H. pylori }\end{array}$ & & $x$ & & $\begin{array}{l}\text { Human AGS stomach } \\
\text { adenocarcinoma cells }\end{array}$ & $\begin{array}{l}\text { Endpoint: IL-8 production. } \\
\text { Bacteria precoated with NPs }\end{array}$ & $\begin{array}{l}\text { Yes, based upon predicted } \\
\text { bacterial surface coverage }\end{array}$ & [76] \\
\hline $\begin{array}{l}50.9 \mathrm{~nm} \\
5 \mathrm{mg} / \mathrm{kg} \\
\mathrm{n} / \mathrm{a}\end{array}$ & P. aeruginosa & $x$ & & $x$ & $\begin{array}{l}\text { In vivo mouse NP } \\
\text { lung pretreatment } \\
\text { followed by challenge }\end{array}$ & $\begin{array}{l}\text { Endpoints: cytokine production } \\
\text { (IL-6, KC, IL-1 } \beta, \text { IL-12, TNF } \alpha \text { ) } \\
\text { and bacterial phagocytosis } \\
\text { (unchanged), mortality } \\
\text { (increased) }\end{array}$ & $\begin{array}{l}\text { No; potential for overdosing } \\
\text { with invasive and } \\
\text { unphysiological nasal } \\
\text { instillation; yes, in relation to } \\
\text { a mechanistic study }\end{array}$ & [83] \\
\hline $\begin{array}{c}\mathrm{Ag} \\
80 \mathrm{~nm} \\
10 \mu \mathrm{g} / \mathrm{mL} \\
\mathrm{n} / \mathrm{a}\end{array}$ & $\begin{array}{l}\text { S. aureus, } \\
\text { E. coli }\end{array}$ & $x$ & & $x$ & $\begin{array}{c}\text { Human } \\
\text { monocyte-derived } \\
\text { macrophages, } \\
\text { osteoclasts }\end{array}$ & $\begin{array}{l}\text { Endpoints: intracellular } \\
\text { bactericidal activity, } \\
\text { ROS generation }\end{array}$ & $\begin{array}{l}\text { Yes, with dose determination } \\
\text { for a functional study and } \\
\text { without relation to } \\
\text { human exposure }\end{array}$ & [96] \\
\hline
\end{tabular}


Table 2. Cont

\begin{tabular}{|c|c|c|c|c|c|c|c|c|}
\hline \multirow[t]{2}{*}{ NP Type (Size, Dose, Shape) } & \multirow[t]{2}{*}{ Stimulus } & \multicolumn{3}{|c|}{$\begin{array}{l}\text { Effect on Bacteria- } \\
\text { Induced Response }\end{array}$} & \multirow[t]{2}{*}{ Cell Type } & \multirow[t]{2}{*}{ Notes } & \multirow{2}{*}{$\begin{array}{l}\text { Discusses NP Dose } \\
\text { Selection }\end{array}$} & \multirow[t]{2}{*}{ Ref } \\
\hline & & $\uparrow$ & $\downarrow$ & $=$ & & & & \\
\hline $\begin{array}{c}\text { Ag-PVP } \\
10,20,80 \mathrm{~nm} 0.78-200 \mu \mathrm{g} / \mathrm{mL} \\
\mathrm{n} / \mathrm{a}\end{array}$ & C. trachomatis & & $x$ & & $\begin{array}{c}\text { Mouse J774 } \\
\text { macrophage-like } \\
\text { histiocytic } \\
\text { lymphoma cells }\end{array}$ & $\begin{array}{l}\text { Endpoint: IL-6, TNF } \alpha \text { and other } \\
\text { cytokines and chemokines) }\end{array}$ & $\begin{array}{c}\text { Yes, dose response to } \\
\text { determine maximal effective } \\
\text { concentration }\end{array}$ & [97] \\
\hline $\begin{array}{l}\text { Iron oxide } \\
100 \mathrm{~nm} \\
3 \mathrm{mg} / \mathrm{mL} \\
\mathrm{n} / \mathrm{a}\end{array}$ & S. aureus & $x$ & & & $\begin{array}{l}\text { Mouse RAW } 264.7 \\
\text { nacrophage-like } \\
\text { leukemia cells, topical } \\
\text { application of NP or } \\
\text { bacteria on the mouse }\end{array}$ & $\begin{array}{c}\text { in vitro: IL-1 } \beta, \mathrm{TNF} \alpha, \mathrm{IL}-12 \\
\text { production, in vivo: CFU } \\
\text { following infection (decreased), } \\
\text { cytokine expression } \\
\text { (IL-1 } \beta \text { increased) }\end{array}$ & Utilized a dose response & [98] \\
\hline $\begin{array}{c}13 \mathrm{~nm} \\
6.25-50 \mu \mathrm{g} / \mathrm{mL} \\
\text { spherical) }\end{array}$ & S. pneumoniae & $x$ & & & $\begin{array}{l}\text { Mouse bone } \\
\text { marrow-derived } \\
\text { macrophages }\end{array}$ & $\begin{array}{l}\text { NP pretreatment resulted in } \\
\text { decreased bacterial } \\
\text { phagocytosis }\end{array}$ & $\begin{array}{c}\text { Yes, allegedly mimicking } \\
\text { occupational exposure doses } \\
\text { (not explained how); particle } \\
\text { kinetics in culture discussed } \\
\text { and macrophage } \\
\text { overload tested }\end{array}$ & {$[56]$} \\
\hline $\begin{array}{c}\mathrm{CuO} \\
12 \mathrm{~nm} \\
3-100 \mu \mathrm{g} / \mathrm{mouse} \\
\text { core/shell }\end{array}$ & K. pneumoniae & $x$ & & & $\begin{array}{l}\text { Murine model of } \\
\text { lung infection }\end{array}$ & $\begin{array}{l}\text { NP toxicity, inflammation (IL- } 6 \text {, } \\
\text { TNF } \alpha, K C \text {, others), and reduced } \\
\text { ability to clear bacteria }\end{array}$ & $\begin{array}{l}\text { Yes, for sub-acute inhalation } \\
\text { dose range mimics human } \\
\text { occupational exposure for } \\
\text { intratracheal instillation } \\
3 \text { concentrations with dose } \\
\text { bridging to human } \\
\text { inhalation exposure }\end{array}$ & [82] \\
\hline $\begin{array}{c}\text { Diesel exhaust particles } \\
\text { n/a } \\
80 \mu \mathrm{g} / \text { mouse } \\
\text { n/a }\end{array}$ & S. pneumoniae & $x$ & & & $\begin{array}{l}\text { Murine model of } \\
\text { lung infection }\end{array}$ & $\begin{array}{l}\text { Mouse more susceptible to } \\
\text { pathogenic infection, increased } \\
\text { lung homogenate cytokines } \\
\text { (IL-6, TNF } \alpha, \text { IL-1 } \beta, \text { KC, others) }\end{array}$ & No rational given & [99] \\
\hline $\begin{array}{l}\text { Welding fumes } \\
100-1000 \mathrm{~nm} \\
600 \mu \mathrm{g} / \text { mouse } \mathrm{n} / \mathrm{a}\end{array}$ & S. pneumoniae & $x$ & & & $\begin{array}{l}\text { Murine model of } \\
\text { lung infection }\end{array}$ & $\begin{array}{c}\text { Increased bacterial CFU in } \\
\text { exposed lungs }\end{array}$ & $\begin{array}{l}\text { No rational beside use of a } \\
\text { high dose }\end{array}$ & [100] \\
\hline
\end{tabular}

H. pylori: Helicobacter pylori; KC: mouse CXCL1; PVP: polyvinylpyrrolidone; P. aeruginosa: Pseudomonas aeruginosa; C. trachomatis: Chlamydia trachomatis; CFU: colony forming units; S. pneumoniae: Staphylococcus pneumoniae; K. pneumoniae: Klebsiella pneumoniae. 


\section{The Long-Term Effects of NP Exposure}

In addition to the possibility that NPs can directly modify immune responses toward bacteria, several indirect and potentially long-term immune consequences of the NP-bacterial interaction should be considered. These include the possibility of improving the immune response in vaccination, the possibility of modulating resident microbiota towards improving human health, and the possibility of inducing/modulating innate memory towards increased resistance to infections.

\subsection{NPs and Vaccines}

Vaccines are among the most significant innovations in modern medicine. Successful vaccination involves two components: (i) presentation of antigen by professional antigen-presenting cells (APCs, typically dendritic cells) to induce adaptive immunity and long-term memory and (ii) innate immune activation, which drives crosstalk between innate and adaptive immune cells, facilitating and amplifying induction of adaptive immunity and memory. NPs can be applied for both functions, i.e., as carriers for improving antigen delivery, and as adjuvants that amplify immune responses and subsequent memory establishment [26,101-103].

NPs can be used to transport and deliver diverse types of antigens such as nucleic acids, proteins, peptides, and immune stimulating agents (adjuvants). Specific NP types have been reported to improve antigen processing and uptake, and prevent premature proteolytic degradation of protein antigens $[104,105]$. Vaccine antigen can be delivered to the target cells by either encapsulation within NPs or by antigen adsorption onto the particle surface. Encapsulation can prevent premature antigen degradation and achieve sustained release, whereas surface adsorption can both stabilize the antigen and facilitate the uptake by APCs through surface receptor-mediated mechanisms [20]. Importantly, intracellular delivery can be tuned so as to achieve presentation of the same antigen both in class I and in class II major histocompatibility complexes, in order to achieve a more complete protective immunity [106]. In addition, the particulate nature of NPs endows them with adjuvant capacity, i.e., the capacity of promoting a localized innate reaction while antigen presentation takes place. All these desirable properties can improve the vaccine delivery and efficacy compared to the other conventional delivery and adjuvant systems [26].

NP types such as inorganic NPs and polymeric NPs have been shown to be efficient antigen carriers. Immunity against Mycobacterium tuberculosis could be enhanced in mice using chitosan NP coated in lipid antigen, enhancing the delivery of antigen to the APCs [107]. Likewise, conjugation of $\mathrm{N}$-terminal domains of flagellin onto Au NPs elicited higher titers of antigen-specific antibodies in mice compared to the carrier-free antigen [76]. Au NPs have also been used as carriers to enhance immunogenicity of antibacterial vaccines against Yersinia pestis, and S. pneumoniae [108-110]. Vetro et al. demonstrated that Au NPs coated with synthetic oligosaccharides corresponding to the repeating units of S. pneumoniae triggered better response to the oligosaccharide epitope (usually poorly immunogenic) and showed similar antibody production in vivo in the mouse as the human PCV13 pneumococcal vaccine (in which diphtheria toxoid is used as a carrier of the pneumococcal polysaccharides) [108].

Furthermore, NPs can be used either directly as adjuvants, or as adjuvant carriers concurrent with antigen. A cationic liposome-based adjuvant stabilized with a synthetic glycolipid (CAF01) could induce a strong and persistent Th1 response to tuberculosis in humans [111] and persistent protective immunity in mice [112]. In the mouse, the adjuvant properties of CAF01 was linked to protracted uptake and activation by dendritic cells [113]. PLGA particles in particular show promise for delivery of multiple molecules simultaneously. By loading PLGA nanoparticles with both TLR4 and TLR7 agonists, Kasturi et al. could demonstrate a synergistic adjuvant effect that greatly enhanced IgG antibody titers against ovalbumin compared to delivery of a single adjuvant [114]. This underlines the potential of using NPs to modulate innate immune responses for the optimal adjuvant effect, and indicates the possibility of fine tuning vaccination strategies against bacterial infection.

In summary, NP-based vaccine formulations are a promising strategy that can induce long-lasting protective memory, as NPs can function as carriers to modulate antigen delivery and improve 
immunogenicity, and they can also act as adjuvants that amplify the induction of protective immunity by a controlled amplification of innate/inflammatory reactions. Developing nanovaccines with optimal safety and efficacy will be of great importance, especially now, in the era of antibiotic resistance.

\subsection{NPs and Microbiota}

Perhaps the most likely avenue for NP interactions with bacteria in a human context occurs within the several locations inhabited by microfloral populations. Figure 3 depicts some potential implications of such NP-bacterial interactions on human innate immunity. The gastro-intestinal tract is colonized by a large and highly interactive community of microbes that play a pivotal role in host health by providing essential nutrients and aiding in digestion. It is now increasingly recognized that these commensal microbiota also contribute to the host immune defense, for example, by providing resistance against invading pathogens and by training and stimulation of the host immune system, as reviewed by $[73,115,116]$. Owing to these critical functions provided by intestinal microbiota, their disruption (dysbiosis) by, for example, a dietary change or a chemical exposure may adversely affect the health of the host [117-119] and in humans is associated to numerous diseases including obesity, inflammatory bowel disease, and diabetes [120]. Given the central role that microbiota play in host immunity and host health, there is a need to incorporate commensal microbiota in the health risk assessment of NP applications, both from a biomedical standpoint, and in the context of occupational, consumptive, or inadvertent NP exposure [121].

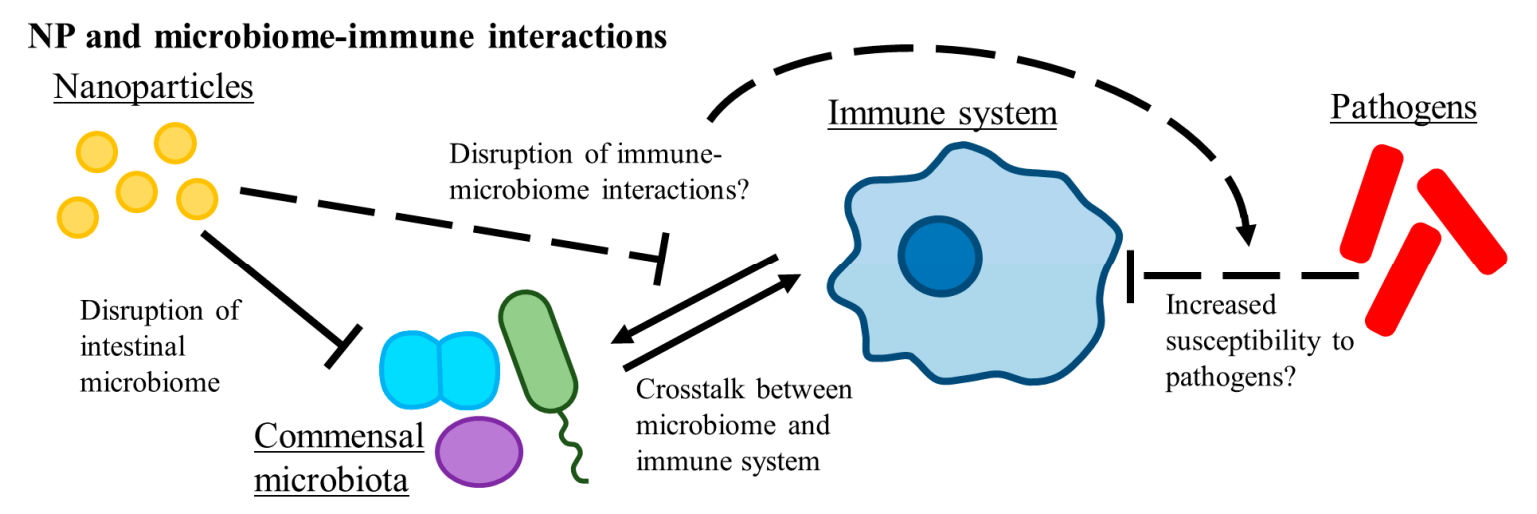

Figure 3. Potential disruption of host microbiota by NPs could lead to altered host immune responses and increased pathogen susceptibility. Solid arrows indicate interactions that are well described in literature. Dashed arrows indicate understudied interactions and possible future focal points for NP research.

An increasing body of literature now indicates that NPs have the potential to disrupt both the gastro-intestinal, but also the respiratory microbiota of animals, as reviewed by [74,118,122-125]. Some studies have indicated that in rodents Ag NPs can negatively affect Lactobacillus and other core intestinal Firmicutes $[126,127]$. These results are, however, contrasted by other findings that show no or a positive impact of Ag NPs on the relative abundance of these bacterial taxa in the intestinal microbiota of rodents [128-130]. Exposure to micro- and nanoplastics has also been proposed as a potential cause of gut dysbiosis $[131,132]$. Further investigation will help reveal the extent by which NPs can disrupt the commensal microbiota and the consequent impact of NPs on gastro-intestinal conditions.

Further, it remains unclear which implications dysbiosis induced by NPs could have on host health $[122,125]$. Some studies have shown that microbiota modulations under NP exposure coincide with changes in the expression of host immune markers [126,127,133], which may reflect the inherent link between microbiota and host immunity. In contrast, other studies have found no relation between microbiota changes and host immune status under NP exposure [134]. A modulation of the expression of immune markers by NPs does not necessarily indicate that the host is being immunocompromised. 
However, a chronic stimulation of intestinal epithelial cells consequent to synergistic NP-microbial effects and leading to a chronic inflammatory milieu in the gut may have critical consequences on barrier integrity and long-term tissue homeostasis. To study whether NPs actually have an adverse effect on the host immune status through dysbiosis, we need animal models in which immunity to infections or other challenges is assessed [134,135]. To date, the possible impact of NPs on the interactions between host immunity, microbiota, and host health status remains largely unexplored, but given the widespread exposure to NPs this clearly requires further investigation.

\subsection{NPs, Bacteria, and Innate Immune Memory}

It is now evident that innate immune cells can develop memory of past challenges, which makes them able to react to subsequent stimulations in a more efficient and more protective fashion. Some stimuli, most notably LPS, drive a tolerance-type memory, in which production of inflammatory effectors is less potent in response to a second challenge, in order to achieve protection without risking the significant tissue damage that a strong reaction to LPS would cause [136,137]. Conversely, in response to other agents (e.g., fungal $\beta$-glucan, oxidized low-density lipoproteins, and BCG) a different type of memory develops, which leads to an increase in cellular reactivity upon a second challenge, again aiming at improving health protection [138-140]. This elevated response has been termed "trained immunity" or "potentiation" [141,142]. Thus, innate immune memory is a protective mechanism, with tolerance shielding the host from excessive inflammation and consequent tissue damage [140], and potentiation enhancing the host defense against unrelated pathogens [143]. Moreover, it appears that innate immune memory may be conferred either locally, for instance within resident macrophages of the lung [144], or systemically via monocyte progenitors in the bone marrow $[145,146]$. In both scenarios, innate immune memory is a long-lasting phenomenon (life-long in invertebrates, at least a few months in humans), despite the shorter lifespan of memory monocytes and macrophages. Most importantly, at variance with immunological memory in adaptive immunity, innate memory in mammals (including human beings) is largely non-specific, meaning that priming (first stimulation) with an agent such as BCG may induce a more powerful secondary response to an unrelated stimulus. Thus, innate memory is apparently one of the mechanisms at the basis of the non-specific protection induced by vaccination/priming that enhances resistance to vaccine-unrelated diseases [147-149].

Since engineered NPs are foreign particles that the innate immune system may recognize as potentially dangerous, it is well possible that they could act as innate memory inducers and/or interfere with memory induction by bacteria and other stimuli. Two scenarios should be considered: (i) that unintentional exposure to NPs or microorganisms together with NPs may erroneously prime the innate immune system for inadequate response to future challenges (e.g., by provoking excessive and destructive inflammation to a subsequent infection) and (ii) that NPs could be used to deliberately induce/modulate innate memory in order to prime the innate immune system towards a more efficient response to future infections, in a sort of non-specific innate vaccination.

In 2017, the first evidence that NPs can induce innate memory was published, which showed a memory effect induced by Au NPs on human primary monocytes and that also hypothesized that the NP-dependent epigenetic reprogramming capacity could be at the basis of innate memory induction [150]. In 2020 several independent reports showed that different NP types could induce innate memory. In the marine bivalve Mytilus galloprovincialis, previous exposure to nanoplastics modulated the hemocyte subpopulations and immune-related genes, resulting in an increased bactericidal capacity upon subsequent exposure to nanopolystyrene [133]. This is the first indication that NPs, similar to bacteria and PAMPs, could induce an innate memory resulting in increased resistance to subsequent infections. Another study demonstrated that pristine graphene (unable to induce cell activation capacity per se) could prime mouse bone marrow-derived macrophages to react to a subsequent challenge with different PAMPs (LPS, CPG, and R848) with an increased production of the inflammatory cytokines IL-6 and $\mathrm{TNF} \alpha$, in parallel to a decreased production of the anti-inflammatory cytokine IL-10, indicating graphene-induced memory reprogrammed macrophages in the direction of immune potentiation, 
despite the apparent inert nature of the nanomaterial [151]. In addition to the capacity of some NPs to induce innate memory, an interesting possibility is that the presence of NPs may modulate the priming/memory-inducing capacity of other agents. Preliminary results indeed show that the memory response of human primary monocytes primed with live BCG and challenged with LPS, in terms of production of inflammatory TNF $\alpha$ and IL- 6 and anti-inflammatory IL-1Ra and IL-10 cytokines was significantly reduced if Au NPs were present with BCG during priming [59]. These findings open the possibility of novel approaches of immunomodulation, in which NPs can be used for improving vaccine efficacy and general resistance to infections, and also for modulating and rebalancing the altered immune responses in a range of immune-related diseases, such as chronic inflammatory, degenerative, and autoimmune diseases [152].

\section{Conclusions and Future Perspectives}

Human exposure to NPs has become increasingly frequent in modern society, both from an occupational and consumer standpoint, and in biomedical applications. Here we addressed the impact that NPs may have on the innate immune response, in particular within the context of the protective response to live bacteria. NPs can interfere with bacterial life, motility, growth, and biofilm formation, and can decrease phagocytosis of bacteria by human immune cells. Since the immune reaction to live bacteria is much more complex than that to PAMPs, generally used in vitro as a bacterial proxy, reliable assays for assessing the capacity of NPs to affect the innate immune response should make use of live bacteria. It also becomes apparent that the NP impact on innate responses to bacterial infection is not limited to the immediate reaction. In vaccination strategies, NPs can facilitate the development of long-lasting specific immunity against pathogenic bacteria at multiple levels: by improving antigen delivery to antigen-presenting cells, by acting as adjuvants that amplify adaptive responses through a controlled inflammatory reaction at the site of antigen presentation, by activating antigen-presenting cells for more efficient antigen presentation, and through modulation of innate memory, which could prime innate immune cells towards a more efficient response to the vaccine. Moreover, NPs may alter the composition of the host microbial community, potentially altering synergism between the host and microflora during immune responses. In each case, in order to understand the full potential impact of NP exposure on human health and innate immunity we need to examine their interactions with live bacteria in suitable in vitro and in vivo models. Overall, based on the most recent data, the possibility of using NPs for modulating innate immune responses towards increased resistance to infections is a promising and realistically feasible possibility.

Author Contributions: Concept: B.J.S., M.H.; collection of articles: B.J.S., M.G., L.J., E.S., S.H., N.H., A.C.F., M.H.; analysis of literature and discussion: B.J.S., A.C.F., S.H., N.H., L.J., M.H.; manuscript drafting; B.J.S., A.C.F., L.J., M.G., M.H., E.S.; design of display items: M.G., M.H., A.C.F., B.J.S.; editing, proof-reading M.H., S.H., N.H., A.D., D.B., P.I.; Funding: A.D., D.B., P.I. All authors have read and agreed to the published version of the manuscript.

Funding: The authors gratefully acknowledge financial support by the International PhD Program "Immunity in Cancer and Allergy" of the Austrian Science Fund (FWF, grant n. W01213), the European Commission Horizon 2020 Framework Programme under grant agreements n. 671881 (PANDORA), n. 812661 (ENDONANO), PRIN project (20173ZECCM), n. 814530 (NanoRigo), n. 731032 (NanoCommons), and the PLUS Allergy-Cancer-BioNano (ACBN) Research Center.

Acknowledgments: Open Access Funding by the Austrian Science Fund (FWF).

Conflicts of Interest: The authors declare no conflict of interest.

\section{References}

1. Marodi, L.; Korchak, H.M.; Johnston, R.B., Jr. Mechanisms of host defense against Candida species. I. Phagocytosis by monocytes and monocyte-derived macrophages. J. Immunol. 1991, 146, 2783-2789. [PubMed]

2. Aderem, A.; Underhill, D.M. Mechanisms of phagocytosis in macrophages. Annu. Rev. Immunol. 1999, 17, 593-623. [CrossRef] [PubMed]

3. Takeuchi, O.; Akira, S. Pattern recognition receptors and inflammation. Cell 2010, 140, 805-820. [CrossRef] 
4. Li, H.; Willingham, S.B.; Ting, J.P.; Re, F. Cutting edge: Inflammasome activation by alum and alum's adjuvant effect are mediated by NLRP3. J. Immunol. 2008, 181, 17-21. [CrossRef]

5. Miller, S.I.; Ernst, R.K.; Bader, M.W. LPS, TLR4 and infectious disease diversity. Nat. Rev. Microbiol. 2005, 3, 36-46. [CrossRef]

6. Li, Y.; Italiani, P.; Casals, E.; Valkenborg, D.; Mertens, I.; Baggerman, G.; Nelissen, I.; Puntes, V.F.; Boraschi, D. Assessing the Immunosafety of Engineered Nanoparticles with a Novel in Vitro Model Based on Human Primary Monocytes. ACS Appl. Mater. Interfaces 2016, 8, 28437-28447. [CrossRef]

7. Elson, G.; Dunn-Siegrist, I.; Daubeuf, B.; Pugin, J. Contribution of Toll-like receptors to the innate immune response to Gram-negative and Gram-positive bacteria. Blood 2007, 109, 1574-1583. [CrossRef]

8. Hornef, M.W.; Wick, M.J.; Rhen, M.; Normark, S. Bacterial strategies for overcoming host innate and adaptive immune responses. Nat. Immunol. 2002, 3, 1033-1040. [CrossRef]

9. Whelan, A.O.; Wright, D.C.; Chambers, M.A.; Singh, M.; Hewinson, R.G.; Vordermeier, H.M. Evidence for enhanced central memory priming by live Mycobacterium bovis BCG vaccine in comparison with killed BCG formulations. Vaccine 2008, 26, 166-173. [CrossRef]

10. Piccinno, F.; Gottschalk, F.; Seeger, S.; Nowack, B. Industrial production quantities and uses of ten engineered nanomaterials in Europe and the world. J. Nanoparticle Res. 2012, 14, 1109. [CrossRef]

11. Mohajerani, A.; Burnett, L.; Smith, J.V.; Kurmus, H.; Milas, J.; Arulrajah, A.; Horpibulsuk, S.; Abdul Kadir, A. Nanoparticles in Construction Materials and Other Applications, and Implications of Nanoparticle Use. Materials 2019, 12, 3051. [CrossRef] [PubMed]

12. Shi, H.; Magaye, R.; Castranova, V.; Zhao, J. Titanium dioxide nanoparticles: A review of current toxicological data. Part. Fibre Toxicol. 2013, 10, 15. [CrossRef]

13. Smolkova, B.; El Yamani, N.; Collins, A.R.; Gutleb, A.C.; Dusinska, M. Nanoparticles in food. Epigenetic changes induced by nanomaterials and possible impact on health. Food Chem. Toxicol. 2015, 77, 64-73. [CrossRef] [PubMed]

14. Dobrovolskaia, M.A.; McNeil, S.E. Immunological properties of engineered nanomaterials. Nat. Nanotechnol. 2007, 2, 469-478. [CrossRef]

15. Nel, A.; Xia, T.; Madler, L.; Li, N. Toxic potential of materials at the nanolevel. Science 2006, 311, 622-627. [CrossRef]

16. Chen, C.; Leong, D.T.; Lynch, I. Rethinking Nanosafety: Harnessing Progress and Driving Innovation. Small 2020, 16, e2002503. [CrossRef]

17. Dulinska-Litewka, J.; Lazarczyk, A.; Halubiec, P.; Szafranski, O.; Karnas, K.; Karewicz, A. Superparamagnetic Iron Oxide Nanoparticles-Current and Prospective Medical Applications. Materials 2019, 12, 617. [CrossRef]

18. Soetaert, F.; Korangath, P.; Serantes, D.; Fiering, S.; Ivkov, R. Cancer therapy with iron oxide nanoparticles: Agents of thermal and immune therapies. Adv. Drug Deliv. Rev. 2020, 163-164, 65-83. [CrossRef]

19. Lu, M.; Cohen, M.H.; Rieves, D.; Pazdur, R. FDA report: Ferumoxytol for intravenous iron therapy in adult patients with chronic kidney disease. Am. J. Hematol. 2010, 85, 315-319. [CrossRef] [PubMed]

20. Yeh, Y.C.; Creran, B.; Rotello, V.M. Gold nanoparticles: Preparation, properties, and applications in bionanotechnology. Nanoscale 2012, 4, 1871-1880. [CrossRef]

21. Rezvantalab, S.; Drude, N.I.; Moraveji, M.K.; Guvener, N.; Koons, E.K.; Shi, Y.; Lammers, T.; Kiessling, F. PLGA-Based Nanoparticles in Cancer Treatment. Front. Pharm. 2018, 9, 1260. [CrossRef] [PubMed]

22. Pandey, A.; Jain, D.S.; Chakraborty, S. Poly Lactic-Co-Glycolic Acid (PLGA) copolymer and its pharmaceutical application. Handb. Polym. Pharm. Technol. 2015, 2, 151-172.

23. Danhier, F.; Ansorena, E.; Silva, J.M.; Coco, R.; Le Breton, A.; Preat, V. PLGA-based nanoparticles: An overview of biomedical applications. J. Control. Release 2012, 161, 505-522. [CrossRef]

24. Tran, S.; DeGiovanni, P.J.; Piel, B.; Rai, P. Cancer nanomedicine: A review of recent success in drug delivery. Clin. Transl Med. 2017, 6, 44. [CrossRef]

25. Yan, X.; Zhou, M.; Yu, S.; Jin, Z.; Zhao, K. An overview of biodegradable nanomaterials and applications in vaccines. Vaccine 2020, 38, 1096-1104. [CrossRef]

26. Boraschi, D.; Italiani, P. From Antigen Delivery System to Adjuvanticy: The Board Application of Nanoparticles in Vaccinology. Vaccines 2015, 3, 930-939. [CrossRef]

27. Johnson, L.; Duschl, A.; Himly, M. Nanotechnology-Based Vaccines for Allergen-Specific Immunotherapy: Potentials and Challenges of Conventional and Novel Adjuvants under Research. Vaccines 2020, 8, 237. [CrossRef] [PubMed] 
28. Kumari, A.; Yadav, S.K.; Yadav, S.C. Biodegradable polymeric nanoparticles based drug delivery systems. Colloids Surf. Biointerfaces 2010, 75, 1-18. [CrossRef] [PubMed]

29. Virkutyte, J.; Varma, R.S. Green synthesis of metal nanoparticles: Biodegradable polymers and enzymes in stabilization and surface functionalization. Chem. Sci. 2011, 2, 837-846. [CrossRef]

30. Panigrahi, S.; Kundu, S.; Ghosh, S.; Nath, S.; Pal, T. General method of synthesis for metal nanoparticles. J. Nanoparticle Res. 2004, 6, 411-414. [CrossRef]

31. Geohegan, D.B.; Puretzky, A.A.; Duscher, G.; Pennycook, S.J. Time-resolved imaging of gas phase nanoparticle synthesis by laser ablation. Appl. Phys. Lett. 1998, 72, 2987-2989. [CrossRef]

32. Li, Y.; Shi, Z.; Radauer-Preiml, I.; Andosch, A.; Casals, E.; Luetz-Meindl, U.; Cobaleda, M.; Lin, Z.; Jaberi-Douraki, M.; Italiani, P.; et al. Bacterial endotoxin (lipopolysaccharide) binds to the surface of gold nanoparticles, interferes with biocorona formation and induces human monocyte inflammatory activation. Nanotoxicology 2017, 11, 1157-1175. [CrossRef] [PubMed]

33. Deschenes, L.; Ells, T. Bacteria-nanoparticle interactions in the context of nanofouling. Adv. Colloid Interface Sci. 2020, 277, 102106. [CrossRef]

34. Lead, J.R.; Batley, G.E.; Alvarez, P.J.J.; Croteau, M.N.; Handy, R.D.; McLaughlin, M.J.; Judy, J.D.; Schirmer, K. Nanomaterials in the environment: Behavior, fate, bioavailability, and effects-An updated review. Environ. Toxicol. Chem. 2018, 37, 2029-2063. [CrossRef] [PubMed]

35. Boraschi, D.; Italiani, P.; Palomba, R.; Decuzzi, P.; Duschl, A.; Fadeel, B.; Moghimi, S.M. Nanoparticles and innate immunity: New perspectives on host defence. Semin. Immunol. 2017, 34, 33-51. [CrossRef]

36. Cronin, J.G.; Jones, N.; Thornton, C.A.; Jenkins, G.J.S.; Doak, S.H.; Clift, M.J.D. Nanomaterials and Innate Immunity: A Perspective of the Current Status in Nanosafety. Chem. Res. Toxicol. 2020, 33, 1061-1073. [CrossRef]

37. Boraschi, D.; Alijagic, A.; Auguste, M.; Barbero, F.; Ferrari, E.; Hernadi, S.; Mayall, C.; Michelini, S.; Navarro Pacheco, N.I.; Prinelli, A.; et al. Addressing Nanomaterial Immunosafety by Evaluating Innate Immunity across Living Species. Small 2020, 16, e2000598. [CrossRef]

38. Brun, E.; Barreau, F.; Veronesi, G.; Fayard, B.; Sorieul, S.; Chaneac, C.; Carapito, C.; Rabilloud, T.; Mabondzo, A.; Herlin-Boime, N.; et al. Titanium dioxide nanoparticle impact and translocation through ex vivo, in vivo and in vitro gut epithelia. Part. Fibre Toxicol. 2014, 11, 13. [CrossRef]

39. Pelclova, D.; Navratil, T.; Kacerova, T.; Zamostna, B.; Fenclova, Z.; Vlckova, S.; Kacer, P. NanoTiO ${ }_{2}$ Sunscreen Does Not Prevent Systemic Oxidative Stress Caused by UV Radiation and a Minor Amount of $\mathrm{NanoTiO}_{2}$ is Absorbed in Humans. Nanomaterials 2019, 9, 888. [CrossRef]

40. Baroli, B.; Ennas, M.G.; Loffredo, F.; Isola, M.; Pinna, R.; Lopez-Quintela, M.A. Penetration of metallic nanoparticles in human full-thickness skin. J. Investig. Derm. 2007, 127, 1701-1712. [CrossRef]

41. Boraschi, D.; Duschl, A. Nanoparticles and the Immune system: Safety and Effects; Academic Press: Oxford, UK, 2013; ISBN 798-0-12-408085-0.

42. Dobrovolskaia, M.A.; Shurin, M.; Shvedova, A.A. Current understanding of interactions between nanoparticles and the immune system. Toxicol. Appl. Pharm. 2016, 299, 78-89. [CrossRef] [PubMed]

43. Dusinska, M.; Tulinska, J.; El Yamani, N.; Kuricova, M.; Liskova, A.; Rollerova, E.; Runden-Pran, E.; Smolkova, B. Immunotoxicity, genotoxicity and epigenetic toxicity of nanomaterials: New strategies for toxicity testing? Food Chem. Toxicol. 2017, 109, 797-811. [CrossRef]

44. Boraschi, D.; Duschl, A. Nanoparticles and the Immune System: Safety and Effects. In Nanoparticles and Immunological Frailty; Academic Press: Oxford, UK, 2013; Chapter 5; pp. 69-74, ISBN 798-0-12-408085-0.

45. Himly, M.; Geppert, M.; Hofer, S.; Hofstatter, N.; Horejs-Hock, J.; Duschl, A. When Would Immunologists Consider a Nanomaterial to be Safe? Recommendations for Planning Studies on Nanosafety. Small 2020, 16, e1907483. [CrossRef] [PubMed]

46. Zaslona, Z.; Palsson-McDermott, E.M.; Menon, D.; Haneklaus, M.; Flis, E.; Prendeville, H.; Corcoran, S.E.; Peters-Golden, M.; O’Neill, L.A.J. The Induction of Pro-IL-1beta by Lipopolysaccharide Requires Endogenous Prostaglandin E2 Production. J. Immunol. 2017, 198, 3558-3564. [CrossRef] [PubMed]

47. Netea, M.G.; Nold-Petry, C.A.; Nold, M.F.; Joosten, L.A.; Opitz, B.; van der Meer, J.H.; van de Veerdonk, F.L.; Ferwerda, G.; Heinhuis, B.; Devesa, I.; et al. Differential requirement for the activation of the inflammasome for processing and release of IL-1beta in monocytes and macrophages. Blood 2009, 113, 2324-2335. [CrossRef] [PubMed] 
48. Swanson, K.V.; Deng, M.; Ting, J.P. The NLRP3 inflammasome: Molecular activation and regulation to therapeutics. Nat. Rev. Immunol. 2019, 19, 477-489. [CrossRef] [PubMed]

49. Dinarello, C.A.; Ikejima, T.; Warner, S.J.; Orencole, S.F.; Lonnemann, G.; Cannon, J.G.; Libby, P. Interleukin 1 induces interleukin 1. I. Induction of circulating interleukin 1 in rabbits in vivo and in human mononuclear cells in vitro. J. Immunol. 1987, 139, 1902-1910.

50. Dinarello, C.A. Overview of the IL-1 family in innate inflammation and acquired immunity. Immunol. Rev. 2018, 281, 8-27. [CrossRef]

51. Baron, L.; Gombault, A.; Fanny, M.; Villeret, B.; Savigny, F.; Guillou, N.; Panek, C.; Le Bert, M.; Lagente, V.; Rassendren, F; et al. The NLRP3 inflammasome is activated by nanoparticles through ATP, ADP and adenosine. Cell Death Dis. 2015, 6, e1629. [CrossRef]

52. Yazdi, A.S.; Guarda, G.; Riteau, N.; Drexler, S.K.; Tardivel, A.; Couillin, I.; Tschopp, J. Nanoparticles activate the NLR pyrin domain containing 3 (Nlrp3) inflammasome and cause pulmonary inflammation through release of IL-1alpha and IL-1beta. Proc. Natl. Acad. Sci. USA 2010, 107, 19449-19454. [CrossRef]

53. Rehman, M.U.; Yoshihisa, Y.; Miyamoto, Y.; Shimizu, T. The anti-inflammatory effects of platinum nanoparticles on the lipopolysaccharide-induced inflammatory response in RAW 264.7 macrophages. Inflamm. Res. 2012, 61, 1177-1185. [CrossRef]

54. Grosse, S.; Stenvik, J.; Nilsen, A.M. Iron oxide nanoparticles modulate lipopolysaccharide-induced inflammatory responses in primary human monocytes. Int. J. Nanomed. 2016, 11, 4625-4642. [CrossRef] [PubMed]

55. Sumbayev, V.V.; Yasinska, I.M.; Garcia, C.P.; Gilliland, D.; Lall, G.S.; Gibbs, B.F.; Bonsall, D.R.; Varani, L.; Rossi, F.; Calzolai, L. Gold nanoparticles downregulate interleukin-1beta-induced pro-inflammatory responses. Small 2013, 9, 472-477. [CrossRef] [PubMed]

56. Kodali, V.; Littke, M.H.; Tilton, S.C.; Teeguarden, J.G.; Shi, L.; Frevert, C.W.; Wang, W.; Pounds, J.G.; Thrall, B.D. Dysregulation of macrophage activation profiles by engineered nanoparticles. Acs Nano 2013, 7, 6997-7010. [CrossRef]

57. Bianchi, M.G.; Allegri, M.; Chiu, M.; Costa, A.L.; Blosi, M.; Ortelli, S.; Bussolati, O.; Bergamaschi, E. Lipopolysaccharide Adsorbed to the Bio-Corona of $\mathrm{TiO}_{2}$ Nanoparticles Powerfully Activates Selected Pro-inflammatory Transduction Pathways. Front. Immunol. 2017, 8, 866. [CrossRef] [PubMed]

58. Conte, C.; Dal Poggetto, G.; Benjamin, J.S.; Esposito, D.; Ungaro, F.; Laurienzo, P.; Boraschi, D.; Quaglia, F. Surface Exposure of PEG and Amines on Biodegradable Nanoparticles as a Strategy to Tune Their Interaction with Protein-Rich Biological Media. Nanomaterials 2019, 9, 1354. [CrossRef]

59. Swartzwelter, B.J.; Barbero, F.; Verde, A.; Mangini, M.; Pirozzi, M.; De Luca, A.C.; Puntes, V.F.; Leite, L.C.C.; Italiani, P.; Boraschi, D. Gold Nanoparticles Modulate BCG-Induced Innate Immune Memory in Human Monocytes by Shifting the Memory Response towards Tolerance. Cells 2020, 9, 284. [CrossRef]

60. Wu, H.Y.; Chung, M.C.; Wang, C.C.; Huang, C.H.; Liang, H.J.; Jan, T.R. Iron oxide nanoparticles suppress the production of IL-1beta via the secretory lysosomal pathway in murine microglial cells. Part. Fibre Toxicol. 2013, 10, 46. [CrossRef]

61. Zanganeh, S.; Hutter, G.; Spitler, R.; Lenkov, O.; Mahmoudi, M.; Shaw, A.; Pajarinen, J.S.; Nejadnik, H.; Goodman, S.; Moseley, M.; et al. Iron oxide nanoparticles inhibit tumour growth by inducing pro-inflammatory macrophage polarization in tumour tissues. Nat. Nanotechnol. 2016, 11, 986-994. [CrossRef]

62. Ferretti, A.M.; Usseglio, S.; Mondini, S.; Drago, C.; La Mattina, R.; Chini, B.; Verderio, C.; Leonzino, M.; Cagnoli, C.; Joshi, P.; et al. Towards bio-compatible magnetic nanoparticles: Immune-related effects, in-vitro internalization, and in-vivo bio-distribution of zwitterionic ferrite nanoparticles with unexpected renal clearance. J. Colloid Interface Sci. 2020, 582, 678-700. [CrossRef]

63. Babazada, H.; Yamashita, F.; Yanamoto, S.; Hashida, M. Self-assembling lipid modified glycol-split heparin nanoparticles suppress lipopolysaccharide-induced inflammation through TLR4-NF-kappaB signaling. J. Control. Release 2014, 194, 332-340. [CrossRef] [PubMed]

64. Lebre, F.; Hanlon, D.; Boland, J.B.; Coleman, J.; Lavelle, E.C. Exfoliation in Endotoxin-Free Albumin Generates Pristine Graphene with Reduced Inflammatory Properties. Adv. Biosyst. 2018, 2, 1800102. [CrossRef]

65. Inoue, K.; Takano, H.; Yanagisawa, R.; Hirano, S.; Sakurai, M.; Shimada, A.; Yoshikawa, T. Effects of airway exposure to nanoparticles on lung inflammation induced by bacterial endotoxin in mice. Environ. Health Perspect. 2006, 114, 1325-1330. [CrossRef] [PubMed] 
66. Hirst, S.M.; Karakoti, A.S.; Tyler, R.D.; Sriranganathan, N.; Seal, S.; Reilly, C.M. Anti-inflammatory properties of cerium oxide nanoparticles. Small 2009, 5, 2848-2856. [CrossRef] [PubMed]

67. Dolgachev, V.A.; Yu, B.; Reinke, J.M.; Raghavendran, K.; Hemmila, M.R. Host susceptibility to gram-negative pneumonia after lung contusion. J. Trauma Acute Care Surg. 2012, 72, 614-622; Discussion 613-622. [CrossRef] [PubMed]

68. Lovewell, R.R.; Patankar, Y.R.; Berwin, B. Mechanisms of phagocytosis and host clearance of Pseudomonas aeruginosa. Am. J. Physiol. Lung Cell Mol. Physiol. 2014, 306, L591-L603. [CrossRef] [PubMed]

69. Huang, Q.Q.; Hossain, M.M.; Wu, K.; Parai, K.; Pope, R.M.; Jin, J.P. Role of H2-calponin in regulating macrophage motility and phagocytosis. J. Biol. Chem. 2008, 283, 25887-25899. [CrossRef]

70. Thurlow, L.R.; Hanke, M.L.; Fritz, T.; Angle, A.; Aldrich, A.; Williams, S.H.; Engebretsen, I.L.; Bayles, K.W.; Horswill, A.R.; Kielian, T. Staphylococcus aureus biofilms prevent macrophage phagocytosis and attenuate inflammation in vivo. J. Immunol. 2011, 186, 6585-6596. [CrossRef]

71. Peng, K.T.; Hsieh, C.C.; Huang, T.Y.; Chen, P.C.; Shih, H.N.; Lee, M.S.; Chang, P.J. Staphylococcus aureus biofilm elicits the expansion, activation and polarization of myeloid-derived suppressor cells in vivo and in vitro. PLoS ONE 2017, 12, e0183271. [CrossRef]

72. Meresse, S.; Steele-Mortimer, O.; Moreno, E.; Desjardins, M.; Finlay, B.; Gorvel, J.P. Controlling the maturation of pathogen-containing vacuoles: A matter of life and death. Nat. Cell Biol. 1999, 1, E183-E188. [CrossRef]

73. Brestoff, J.R.; Artis, D. Commensal bacteria at the interface of host metabolism and the immune system. Nat. Immunol. 2013, 14, 676-684. [CrossRef] [PubMed]

74. Poh, T.Y.; Ali, N.; Mac Aogain, M.; Kathawala, M.H.; Setyawati, M.I.; Ng, K.W.; Chotirmall, S.H. Inhaled nanomaterials and the respiratory microbiome: Clinical, immunological and toxicological perspectives. Part. Fibre Toxicol. 2018, 15, 46. [CrossRef] [PubMed]

75. Schafer-Korting, M.; Mehnert, W.; Korting, H.C. Lipid nanoparticles for improved topical application of drugs for skin diseases. Adv. Drug Deliv. Rev. 2007, 59, 427-443. [CrossRef] [PubMed]

76. Westmeier, D.; Posselt, G.; Hahlbrock, A.; Bartfeld, S.; Vallet, C.; Abfalter, C.; Docter, D.; Knauer, S.K.; Wessler, S.; Stauber, R.H. Nanoparticle binding attenuates the pathobiology of gastric cancer-associated Helicobacter pylori. Nanoscale 2018, 10, 1453-1463. [CrossRef]

77. Khan, F.; Manivasagan, P.; Lee, J.W.; Pham, D.T.N.; Oh, J.; Kim, Y.M. Fucoidan-Stabilized Gold Nanoparticle-Mediated Biofilm Inhibition, Attenuation of Virulence and Motility Properties in Pseudomonas aeruginosa PAO1. Mar. Drugs 2019, 17, 208. [CrossRef] [PubMed]

78. Bancos, S.; Stevens, D.L.; Tyner, K.M. Effect of silica and gold nanoparticles on macrophage proliferation, activation markers, cytokine production, and phagocytosis in vitro. Int. J. Nanomed. 2015, 10, 183-206. [CrossRef]

79. Li, J.; Cha, R.; Zhao, X.; Guo, H.; Luo, H.; Wang, M.; Zhou, F.; Jiang, X. Gold Nanoparticles Cure Bacterial Infection with Benefit to Intestinal Microflora. Acs Nano 2019, 13, 5002-5014. [CrossRef] [PubMed]

80. Coggon, D.; Palmer, K.T. Are welders more at risk of respiratory infections? Thorax 2016, 71, 581-582. [CrossRef]

81. Ewing, J.; Patterson, L.; Irvine, N.; Doherty, L.; Loughrey, A.; Kidney, J.; Sheppard, C.; Kapatai, G.; Fry, N.K.; Ramsay, M.; et al. Serious pneumococcal disease outbreak in men exposed to metal fume-Detection, response and future prevention through pneumococcal vaccination. Vaccine 2017, 35, 3945-3950. [CrossRef]

82. Kim, J.S.; Adamcakova-Dodd, A.; O'Shaughnessy, P.T.; Grassian, V.H.; Thorne, P.S. Effects of copper nanoparticle exposure on host defense in a murine pulmonary infection model. Part. Fibre Toxicol. 2011, 8, 29. [CrossRef]

83. Delaval, M.; Boland, S.; Solhonne, B.; Nicola, M.A.; Mornet, S.; Baeza-Squiban, A.; Sallenave, J.M.; Garcia-Verdugo, I. Acute exposure to silica nanoparticles enhances mortality and increases lung permeability in a mouse model of Pseudomonas aeruginosa pneumonia. Part. Fibre Toxicol. 2015, 12, 1. [CrossRef] [PubMed]

84. Setyawati, M.I.; Tay, C.Y.; Chia, S.L.; Goh, S.L.; Fang, W.; Neo, M.J.; Chong, H.C.; Tan, S.M.; Loo, S.C.; $\mathrm{Ng}$, K.W.; et al. Titanium dioxide nanomaterials cause endothelial cell leakiness by disrupting the homophilic interaction of VE-cadherin. Nat. Commun. 2013, 4, 1673. [CrossRef] [PubMed]

85. Liu, J.; Vipulanandan, C. Effects of $\mathrm{Au} / \mathrm{Fe}$ and Fe nanoparticles on Serratia bacterial growth and production of biosurfactant. Mater. Sci. Eng. C Mater. Biol Appl. 2013, 33, 3909-3915. [CrossRef]

86. Woo, M.; Wood, C.; Kwon, D.; Park, K.P.; Fejer, G.; Delorme, V. Mycobacterium tuberculosis Infection and Innate Responses in a New Model of Lung Alveolar Macrophages. Front. Immunol. 2018, 9, 438. [CrossRef] 
87. Feng, Q.L.; Wu, J.; Chen, G.Q.; Cui, F.Z.; Kim, T.N.; Kim, J.O. A mechanistic study of the antibacterial effect of silver ions on Escherichia coli and Staphylococcus aureus. J. Biomed. Mater. Res. 2000, 52, 662-668. [CrossRef]

88. Morones, J.R.; Elechiguerra, J.L.; Camacho, A.; Holt, K.; Kouri, J.B.; Ramirez, J.T.; Yacaman, M.J. The bactericidal effect of silver nanoparticles. Nanotechnology 2005, 16, 2346-2353. [CrossRef] [PubMed]

89. Markowska, K.; Grudniak, A.M.; Wolska, K.I. Silver nanoparticles as an alternative strategy against bacterial biofilms. Acta Biochim. Pol. 2013, 60, 523-530. [CrossRef]

90. Borcherding, J.; Baltrusaitis, J.; Chen, H.; Stebounova, L.; Wu, C.M.; Rubasinghege, G.; Mudunkotuwa, I.A.; Caraballo, J.C.; Zabner, J.; Grassian, V.H.; et al. Iron oxide nanoparticles induce Pseudomonas aeruginosa growth, induce biofilm formation, and inhibit antimicrobial peptide function. Environ. Sci. Nano 2014, 1, 123-132. [CrossRef]

91. Seil, J.T.; Webster, T.J. Antimicrobial applications of nanotechnology: Methods and literature. Int. J. Nanomed. 2012, 7, 2767-2781. [CrossRef]

92. Bernardos, A.; Piacenza, E.; Sancenon, F.; Hamidi, M.; Maleki, A.; Turner, R.J.; Martinez-Manez, R. Mesoporous Silica-Based Materials with Bactericidal Properties. Small 2019, 15, e1900669. [CrossRef] [PubMed]

93. Lee, N.Y.; Ko, W.C.; Hsueh, P.R. Nanoparticles in the Treatment of Infections Caused by Multidrug-Resistant Organisms. Front. Pharm. 2019, 10, 1153. [CrossRef] [PubMed]

94. Bianco, C.; Visser, M.J.; Pluut, O.A.; Svetlicic, V.; Pletikapic, G.; Jakasa, I.; Riethmuller, C.; Adami, G.; Larese Filon, F.; Schwegler-Berry, D.; et al. Characterization of silver particles in the stratum corneum of healthy subjects and atopic dermatitis patients dermally exposed to a silver-containing garment. Nanotoxicology 2016, 10, 1480-1491. [CrossRef] [PubMed]

95. Lepper, P.M.; Held, T.K.; Schneider, E.M.; Bolke, E.; Gerlach, H.; Trautmann, M. Clinical implications of antibiotic-induced endotoxin release in septic shock. Intensive Care Med. 2002, 28, 824-833. [CrossRef] [PubMed]

96. Aurore, V.; Caldana, F.; Blanchard, M.; Kharoubi Hess, S.; Lannes, N.; Mantel, P.Y.; Filgueira, L.; Walch, M. Silver-nanoparticles increase bactericidal activity and radical oxygen responses against bacterial pathogens in human osteoclasts. Nanomedicine 2018, 14, 601-607. [CrossRef]

97. Yilma, A.N.; Singh, S.R.; Dixit, S.; Dennis, V.A. Anti-inflammatory effects of silver-polyvinyl pyrrolidone (Ag-PVP) nanoparticles in mouse macrophages infected with live Chlamydia trachomatis. Int. J. Nanomed. 2013, 8, 2421-2432. [CrossRef]

98. Yu, B.; Wang, Z.; Almutairi, L.; Huang, S.; Kim, M.H. Harnessing iron-oxide nanoparticles towards the improved bactericidal activity of macrophage against Staphylococcus aureus. Nanomedicine 2020, 24, 102158. [CrossRef]

99. Shears, R.K.; Jacques, L.C.; Naylor, G.; Miyashita, L.; Khandaker, S.; Lebre, F.; Lavelle, E.C.; Grigg, J.; French, N.; Neill, D.R.; et al. Exposure to diesel exhaust particles increases susceptibility to invasive pneumococcal disease. J. Allergy Clin. Immunol. 2020, 145, 1272-1284.e6. [CrossRef]

100. Suri, R.; Periselneris, J.; Lanone, S.; Zeidler-Erdely, P.C.; Melton, G.; Palmer, K.T.; Andujar, P.; Antonini, J.M.; Cohignac, V.; Erdely, A.; et al. Exposure to welding fumes and lower airway infection with Streptococcus pneumoniae. J. Allergy Clin. Immunol. 2016, 137, 527-534. [CrossRef]

101. Du, J.; Zhang, Y.S.; Hobson, D.; Hydbring, P. Nanoparticles for immune system targeting. Drug Discov. Today 2017, 22, 1295-1301. [CrossRef]

102. Slutter, B.; Plapied, L.; Fievez, V.; Sande, M.A.; des Rieux, A.; Schneider, Y.J.; Van Riet, E.; Jiskoot, W.; Preat, V. Mechanistic study of the adjuvant effect of biodegradable nanoparticles in mucosal vaccination. J. Control. Release 2009, 138, 113-121. [CrossRef]

103. Zhu, M.; Wang, R.; Nie, G. Applications of nanomaterials as vaccine adjuvants. Hum. Vaccines Immunother. 2014, 10, 2761-2774. [CrossRef] [PubMed]

104. Joshi, V.B.; Geary, S.M.; Salem, A.K. Biodegradable particles as vaccine delivery systems: Size matters. AAPS J. 2013, 15, 85-94. [CrossRef] [PubMed]

105. Yu, M.; Wu, J.; Shi, J.; Farokhzad, O.C. Nanotechnology for protein delivery: Overview and perspectives. J. Control. Release 2016, 240, 24-37. [CrossRef] [PubMed]

106. Firdous, J.; Islam, M.A.; Park, S.M.; Cheon, I.S.; Shim, B.S.; Yoon, H.S.; Song, M.; Chang, J.; Choi, Y.J.; Park, Y.M.; et al. Induction of long-term immunity against respiratory syncytial virus glycoprotein by an osmotic polymeric nanocarrier. Acta Biomater. 2014, 10, 4606-4617. [CrossRef] 
107. Das, I.; Padhi, A.; Mukherjee, S.; Dash, D.P.; Kar, S.; Sonawane, A. Biocompatible chitosan nanoparticles as an efficient delivery vehicle for Mycobacterium tuberculosis lipids to induce potent cytokines and antibody response through activation of gammadelta T cells in mice. Nanotechnology 2017, 28, 165101. [CrossRef]

108. Vetro, M.; Safari, D.; Fallarini, S.; Salsabila, K.; Lahmann, M.; Penades, S.; Lay, L.; Marradi, M.; Compostella, F. Preparation and immunogenicity of gold glyco-nanoparticles as antipneumococcal vaccine model. Nanomedicine (Lond.) 2017, 12,13-23. [CrossRef]

109. Safari, D.; Marradi, M.; Chiodo, F.; Th Dekker, H.A.; Shan, Y.; Adamo, R.; Oscarson, S.; Rijkers, G.T.; Lahmann, M.; Kamerling, J.P.; et al. Gold nanoparticles as carriers for a synthetic Streptococcus pneumoniae type 14 conjugate vaccine. Nanomedicine (Lond.) 2012, 7, 651-662. [CrossRef]

110. Gregory, A.E.; Williamson, E.D.; Prior, J.L.; Butcher, W.A.; Thompson, I.J.; Shaw, A.M.; Titball, R.W. Conjugation of Y. pestis F1-antigen to gold nanoparticles improves immunogenicity. Vaccine 2012, 30, 6777-6782. [CrossRef]

111. van Dissel, J.T.; Joosten, S.A.; Hoff, S.T.; Soonawala, D.; Prins, C.; Hokey, D.A.; O’Dee, D.M.; Graves, A.; Thierry-Carstensen, B.; Andreasen, L.V.; et al. A novel liposomal adjuvant system, CAF01, promotes long-lived Mycobacterium tuberculosis-specific T-cell responses in human. Vaccine 2014, 32, 7098-7107. [CrossRef]

112. Woodworth, J.S.; Cohen, S.B.; Moguche, A.O.; Plumlee, C.R.; Agger, E.M.; Urdahl, K.B.; Andersen, P. Subunit vaccine H56/CAF01 induces a population of circulating CD4 T cells that traffic into the Mycobacterium tuberculosis-infected lung. Mucosal Immunol. 2017, 10, 555-564. [CrossRef]

113. Kamath, A.T.; Rochat, A.F.; Christensen, D.; Agger, E.M.; Andersen, P.; Lambert, P.H.; Siegrist, C.A. A liposome-based mycobacterial vaccine induces potent adult and neonatal multifunctional $\mathrm{T}$ cells through the exquisite targeting of dendritic cells. PLOS ONE 2009, 4, e5771. [CrossRef] [PubMed]

114. Kasturi, S.P.; Skountzou, I.; Albrecht, R.A.; Koutsonanos, D.; Hua, T.; Nakaya, H.I.; Ravindran, R.; Stewart, S.; Alam, M.; Kwissa, M.; et al. Programming the magnitude and persistence of antibody responses with innate immunity. Nature 2011, 470, 543-547. [CrossRef]

115. Belkaid, Y.; Harrison, O.J. Homeostatic Immunity and the Microbiota. Immunity 2017, 46, 562-576. [CrossRef] [PubMed]

116. Buffie, C.G.; Pamer, E.G. Microbiota-mediated colonization resistance against intestinal pathogens. Nat. Rev. Immunol. 2013, 13, 790-801. [CrossRef]

117. Chiu, K.; Warner, G.; Nowak, R.A.; Flaws, J.A.; Mei, W. The Impact of Environmental Chemicals on the Gut Microbiome. Toxicol. Sci. 2020, 176, 253-284. [CrossRef] [PubMed]

118. Rosenfeld, C.S. Gut Dysbiosis in Animals Due to Environmental Chemical Exposures. Front. Cell Infect. Microbiol. 2017, 7, 396. [CrossRef] [PubMed]

119. Zheng, D.; Liwinski, T.; Elinav, E. Interaction between microbiota and immunity in health and disease. Cell Res. 2020, 30, 492-506. [CrossRef]

120. Clemente, J.C.; Ursell, L.K.; Parfrey, L.W.; Knight, R. The impact of the gut microbiota on human health: An integrative view. Cell 2012, 148, 1258-1270. [CrossRef]

121. Dietert, R.R.; Silbergeld, E.K. Biomarkers for the 21st century: Listening to the microbiome. Toxicol. Sci. 2015, 144, 208-216. [CrossRef]

122. Bouwmeester, H.; van der Zande, M.; Jepson, M.A. Effects of food-borne nanomaterials on gastrointestinal tissues and microbiota. Wiley Interdiscip. Rev. Nanomed. Nanobiotechnol. 2018, 10, e1481. [CrossRef]

123. Jin, Y.; Wu, S.; Zeng, Z.; Fu, Z. Effects of environmental pollutants on gut microbiota. Envion. Pollut. 2017, 222, 1-9. [CrossRef]

124. Pietroiusti, A.; Magrini, A.; Campagnolo, L. New frontiers in nanotoxicology: Gut microbiota/microbiomemediated effects of engineered nanomaterials. Toxicol. Appl. Pharm. 2016, 299, 90-95. [CrossRef]

125. Zhang, Y.; Mortimer, M.; Guo, L.-H. Interplay between engineered nanomaterials and microbiota. Environ. Sci. Nano 2020, 7, 2454-2485. [CrossRef]

126. Chen, H.; Zhao, R.; Wang, B.; Cai, C.; Zheng, L.; Wang, H.; Wang, M.; Ouyang, H.; Zhou, X.; Chai, Z. The effects of orally administered $\mathrm{Ag}, \mathrm{TiO}_{2}$ and $\mathrm{SiO}_{2}$ nanoparticles on gut microbiota composition and colitis induction in mice. NanoImpact 2017, 8, 80-88. [CrossRef]

127. Williams, K.; Milner, J.; Boudreau, M.D.; Gokulan, K.; Cerniglia, C.E.; Khare, S. Effects of subchronic exposure of silver nanoparticles on intestinal microbiota and gut-associated immune responses in the ileum of Sprague-Dawley rats. Nanotoxicology 2015, 9, 279-289. [CrossRef] [PubMed] 
128. Javurek, A.B.; Suresh, D.; Spollen, W.G.; Hart, M.L.; Hansen, S.A.; Ellersieck, M.R.; Bivens, N.J.; Givan, S.A.; Upendran, A.; Kannan, R.; et al. Gut Dysbiosis and Neurobehavioral Alterations in Rats Exposed to Silver Nanoparticles. Sci. Rep. 2017, 7, 2822. [CrossRef]

129. van den Brule, S.; Ambroise, J.; Lecloux, H.; Levard, C.; Soulas, R.; De Temmerman, P.J.; Palmai-Pallag, M.; Marbaix, E.; Lison, D. Dietary silver nanoparticles can disturb the gut microbiota in mice. Part. Fibre Toxicol. 2016, 13, 38. [CrossRef]

130. Wilding, L.A.; Bassis, C.M.; Walacavage, K.; Hashway, S.; Leroueil, P.R.; Morishita, M.; Maynard, A.D.; Philbert, M.A.; Bergin, I.L. Repeated dose (28-day) administration of silver nanoparticles of varied size and coating does not significantly alter the indigenous murine gut microbiome. Nanotoxicology 2016, 10, 513-520. [CrossRef]

131. Fackelmann, G.; Sommer, S. Microplastics and the gut microbiome: How chronically exposed species may suffer from gut dysbiosis. Mar. Pollut. Bull. 2019, 143, 193-203.

132. Hirt, N.; Body-Malapel, M. Immunotoxicity and intestinal effects of nano-and microplastics: A review of the literature. Part. Fibre Toxicol. 2020, 17, 57. [CrossRef]

133. Auguste, M.; Balbi, T.; Ciacci, C.; Canonico, B.; Papa, S.; Borello, A.; Vezzulli, L.; Canesi, L. Shift in Immune Parameters After Repeated Exposure to Nanoplastics in the Marine Bivalve Mytilus. Front. Immunol. 2020, 11, 426. [CrossRef] [PubMed]

134. Swart, E.; Dvorak, J.; Hernadi, S.; Goodall, T.; Kille, P.; Spurgeon, D.; Svendsen, C.; Prochazkova, P. The Effects of In Vivo Exposure to Copper Oxide Nanoparticles on the Gut Microbiome, Host Immunity, and Susceptibility to a Bacterial Infection in Earthworms. Nanomaterials 2020, 10, 1337. [CrossRef] [PubMed]

135. Boraschi, D.; Oostingh, G.J.; Casals, E.; Italiani, P.; Nelissen, I.; Puntes, V.F.; Duschl, A. Nano-immunosafety: Issues in assay validation. J. Phys. Conf. Ser. 2011, 304, 012077. [CrossRef]

136. Seeley, J.J.; Ghosh, S. Molecular mechanisms of innate memory and tolerance to LPS. J. Leukoc. Biol. 2017, 101, 107-119. [CrossRef] [PubMed]

137. Freudenberg, M.A.; Galanos, C. Induction of tolerance to lipopolysaccharide (LPS)-D-galactosamine lethality by pretreatment with LPS is mediated by macrophages. Infect. Immun. 1988, 56, 1352-1357. [CrossRef]

138. Arts, R.J.W.; Moorlag, S.; Novakovic, B.; Li, Y.; Wang, S.Y.; Oosting, M.; Kumar, V.; Xavier, R.J.; Wijmenga, C.; Joosten, L.A.B.; et al. BCG Vaccination Protects against Experimental Viral Infection in Humans through the Induction of Cytokines Associated with Trained Immunity. Cell Host Microbe 2018, 23, 89-100.e5. [CrossRef]

139. Bekkering, S.; Quintin, J.; Joosten, L.A.; van der Meer, J.W.; Netea, M.G.; Riksen, N.P. Oxidized low-density lipoprotein induces long-term proinflammatory cytokine production and foam cell formation via epigenetic reprogramming of monocytes. Arter. Thromb. Vasc. Biol. 2014, 34, 1731-1738. [CrossRef]

140. Quintin, J.; Saeed, S.; Martens, J.H.A.; Giamarellos-Bourboulis, E.J.; Ifrim, D.C.; Logie, C.; Jacobs, L.; Jansen, T.; Kullberg, B.J.; Wijmenga, C.; et al. Candida albicans infection affords protection against reinfection via functional reprogramming of monocytes. Cell Host Microbe 2012, 12, 223-232. [CrossRef]

141. Boraschi, D.; Italiani, P. Innate Immune Memory: Time for Adopting a Correct Terminology. Front. Immunol. 2018, 9, 799. [CrossRef]

142. Netea, M.G.; Joosten, L.A.; Latz, E.; Mills, K.H.; Natoli, G.; Stunnenberg, H.G.; O’Neill, L.A.; Xavier, R.J. Trained immunity: A program of innate immune memory in health and disease. Science 2016, 352, aaf1098. [CrossRef]

143. Netea, M.G.; Quintin, J.; Van Der Meer, J.W. Trained immunity: A memory for innate host defense. Cell Host Microbe 2011, 9, 355-361. [CrossRef] [PubMed]

144. Netea, M.G.; Joosten, L.A.B. Trained Immunity and Local Innate Immune Memory in the Lung. Cell 2018, 175, 1463-1465. [CrossRef] [PubMed]

145. Kaufmann, E.; Sanz, J.; Dunn, J.L.; Khan, N.; Mendonca, L.E.; Pacis, A.; Tzelepis, F.; Pernet, E.; Dumaine, A.; Grenier, J.C.; et al. BCG Educates Hematopoietic Stem Cells to Generate Protective Innate Immunity against Tuberculosis. Cell 2018, 172, 176-190.e19. [CrossRef]

146. Mitroulis, I.; Ruppova, K.; Wang, B.; Chen, L.S.; Grzybek, M.; Grinenko, T.; Eugster, A.; Troullinaki, M.; Palladini, A.; Kourtzelis, I.; et al. Modulation of Myelopoiesis Progenitors Is an Integral Component of Trained Immunity. Cell 2018, 172, 147-161.e12. [CrossRef] [PubMed]

147. Berendsen, M.L.; Bles, P.; de Bree LC, J.; Jensen, K.J.; Jensen, C.C.; Wejse, C.; Mendes, D.V.; Netea, M.G.; Benn, C.S. BCG Vaccination Induces Trained Innate Immunity in Adults Over 50 Years of Age: A Randomized Trial in Guinea-Bissau. Cell Rep. Med. 2020. [CrossRef] 
148. Hirve, S.; Bavdekar, A.; Juvekar, S.; Benn, C.S.; Nielsen, J.; Aaby, P. Non-specific and sex-differential effects of vaccinations on child survival in rural western India. Vaccine 2012, 30, 7300-7308. [CrossRef]

149. Moorlag, S.; Khan, N.; Novakovic, B.; Kaufmann, E.; Jansen, T.; van Crevel, R.; Divangahi, M.; Netea, M.G. beta-Glucan Induces Protective Trained Immunity against Mycobacterium tuberculosis Infection: A Key Role for IL-1. Cell Rep. 2020, 31, 107634. [CrossRef]

150. Italiani, P.; Boraschi, D. Induction of Innate Immune Memory by Engineered Nanoparticles: A Hypothesis That May Become True. Front. Immunol. 2017, 8, 734. [CrossRef]

151. Lebre, F.; Boland, J.B.; Gouveia, P.; Gorman, A.L.; Lundahl, M.L.E.; Roisin, I.L.; O’Brien, F.J.; Coleman, J.; Lavelle, E.C. Pristine graphene induces innate immune training. Nanoscale 2020, 12, 11192-11200. [CrossRef]

152. Italiani, P.; Della Camera, G.; Boraschi, D. Induction of Innate Immune Memory by Engineered Nanoparticles in Monocytes/Macrophages: From Hypothesis to Reality. Front. Immunol. 2020, 11, 2324. [CrossRef]

Publisher's Note: MDPI stays neutral with regard to jurisdictional claims in published maps and institutional affiliations.

(C) 2020 by the authors. Licensee MDPI, Basel, Switzerland. This article is an open access article distributed under the terms and conditions of the Creative Commons Attribution (CC BY) license (http://creativecommons.org/licenses/by/4.0/). 